\title{
AMULETOS FÁLICOS ROMANOS DE LA PROVINCIA DE CÁDIZ
}

\section{ROMAN PHALLIC AMULETS FROM THE PROVINCE OF CADIZ}

\section{Álvaro GÓMEZ PEÑA ${ }^{1 *}$, Amanda BRAVO HIDALGO** y Jesús RODRÍGUEZ MELLADO**}

\author{
${ }^{1}$ Profesor Sustituto Interino de Prehistoria, Departamento de Prehistoria y Arqueología, Universidad de \\ Sevilla, Calle Doña María de Padilla s/n 41004, Sevilla \\ ${ }^{2}$ Arqueóloga profesional \\ ${ }^{3}$ Arqueólogo profesional \\ * Correo electrónico: agomez19@us.es \\ ** Correo electrónico: amandabravohidalgo1@gmail.com \\ *** Correo electrónico: jesusrodriguezmellado@hotmail.com
}

Resumen: En el presente artículo se publican un total de veintidós amuletos fálicos de época romana procedentes de la provincia de Cádiz, quedando pendientes para otra ocasión las piezas procedentes de la capital gaditana. Entre ellos cabe destacar un ejemplar realizado en oro y otro en forma de pelta, cuya tipología se desconocía hasta el presente en la Bética. Además de dar a conocer dicho corpus, se analiza en un segundo apartado la creencia en el mal de ojo en época romana, reparando en las propuestas emic y etic que se han dado sobre el porqué del empleo de elementos de simbología fálica para evitarlo.

Palabras Clave: Amuleto fálico, higa, Cádiz, creencias apotropaicas, arqueología funeraria.

Abstract: Twenty-two phallic Roman amulets from the province of Cadiz are published, still remaining the pieces from the capital for a forthcoming publication. A piece made of gold and other in the shape of 'pelta', whose typology was unknown until now in Baetica, are highlighted among them. In addition, the belief in the evil eye in Roman times is analyzed in a second section, paying attention to emic and etic proposals according to phallic symbolism to avoid it.

Keywords: phallic amulet, figa, Cadiz, apotropaic beliefs, funerary archaeology.

Sumario: 1. Introducción. 2. Amuletos fálicos. 2.1. Regla (Chipiona). 2.2. Avenida de Sevilla, 86 (Chipiona). 2.3. Las Tres Piedras (Chipiona). 2.4. Mesas de Asta (Jerez de la Frontera, Cádiz). 2.5. Gibalbín (Jerez de la Frontera). 2.6. Vega del Torno (Jerez de la Frontera). 2.7. Cortijo Fuensanta (Arcos de la Frontera). 2.8. Sierra de San Cristóbal (El Puerto de Santa María). 2.9. Esperilla (Espera). 2.10. Asido Caesarina (Medina Sidonia). 2.11. Baelo Claudia (Tarifa). 2.12. ¿Cerro de la Botinera? (Los Algodonales). 3. El mal de ojo y los amuletos fálicos en época romana. 3.1. ¿Quiénes podían transmitir el mal de ojo? 3.2. ¿Cómo se transmitía el mal de ojo? 3.3. ¿Cómo se podía evitar el mal de ojo? 3.4. ¿Por qué se usaban símbolos fálicos contra el mal de ojo? 4. A modo de conclusión. 5. Agradecimientos. 6. Bibliografía.

\section{Introducción}

El pudor a publicar amuletos fálicos hasta hace algunas décadas y el desconocimiento de la posesión de éstos por parte de coleccionistas privados han hecho que durante mucho tiempo el estudio de estos objetos fuese una cuestión pendiente. Afortunadamente, desde la década de los sesenta del pasado siglo, y con más intensidad en la península Ibérica desde los años ochenta, este asunto ha visto un cambio de tendencia hasta el punto de que se han publicado numerosos amuletos y se han llegado a proponer varias clasificaciones tipológicas (Andreu y Urrizburu, 2019; Barreiro, 2004, 2011; De la Barrera y Velázquez, 1988; Del Hoyo y Vázquez, 1994; Galve, 1983; Gómez, 2008; Gómez y Mellado, 2013; Morena y Romero, 2015; Rolland, 1965: 176-181; 1996; Sáenz y Lasuén, 2004; Vázquez Hoys, 2009; Zarzalejos et al., 1988). 
El resultado de esta creciente predilección por los amuletos fálicos y por el estudio del mal de ojo, al que estas piezas trataban de hacer frente, han sido ampliamente tratados en una tesis doctoral que se antojaba necesaria (Alvar, 2010). No obstante, todavía está pendiente de realización un corpus lo más completo posible sobre este tipo de objetos en el que se traten de aclarar aspectos tales como su fabricación, distribución, frecuencia de uso en diferentes momentos y regiones, ampliación de las clasificaciones tipológicas propuestas, evolución tipológica a partir de los casos bien contextualizados y pautas de uso durante el proceso de romanización.

A la espera de ese trabajo, en este texto se recogen un total de veintidós amuletos fálicos depositados actualmente en diferentes museos de la provincia de Cádiz (Figura 1). A falta de un motivo de peso aparente para enumerarlos de otra manera, se presentan en el mismo orden en que fueron estudiados por nosotros. Se presenta así el corpus más amplio de este tipo de piezas conocido hasta el momento dentro de la península Ibérica. Todos los ejemplares aquí analizados tienen como denominador común, además de su adscripción romana, el hecho de estar facturados en metal y el haber sido localizados fuera de la capital gaditana. De todos ellos, tan solo cinco fueron dados a conocer de modo muy sucinto previamente, por lo que se incluyen aquí nuevamente aportando fotografías y datos nuevos sobre sus contextos.

No se trata en ningún caso de la totalidad de piezas halladas en la provincia gaditana, dado que en el Museo de Cádiz existe más de medio centenar de ejemplares de diversas materias y tipologías procedentes de la capital (vid. Barreiro, 2004, 2011). No obstante, aunque hemos tenido ocasión de estudiar este amplio conjunto, por las lógicas limitaciones de espacio que conlleva una publicación como el presente artículo deberán ser tratados en futuras publicaciones; igualmente, además de estas veintidós piezas, en las siguientes páginas se recogen noticias de varios amuletos fálicos procedentes de los municipios tratados de los cuales desconocemos sus paraderos actuales.

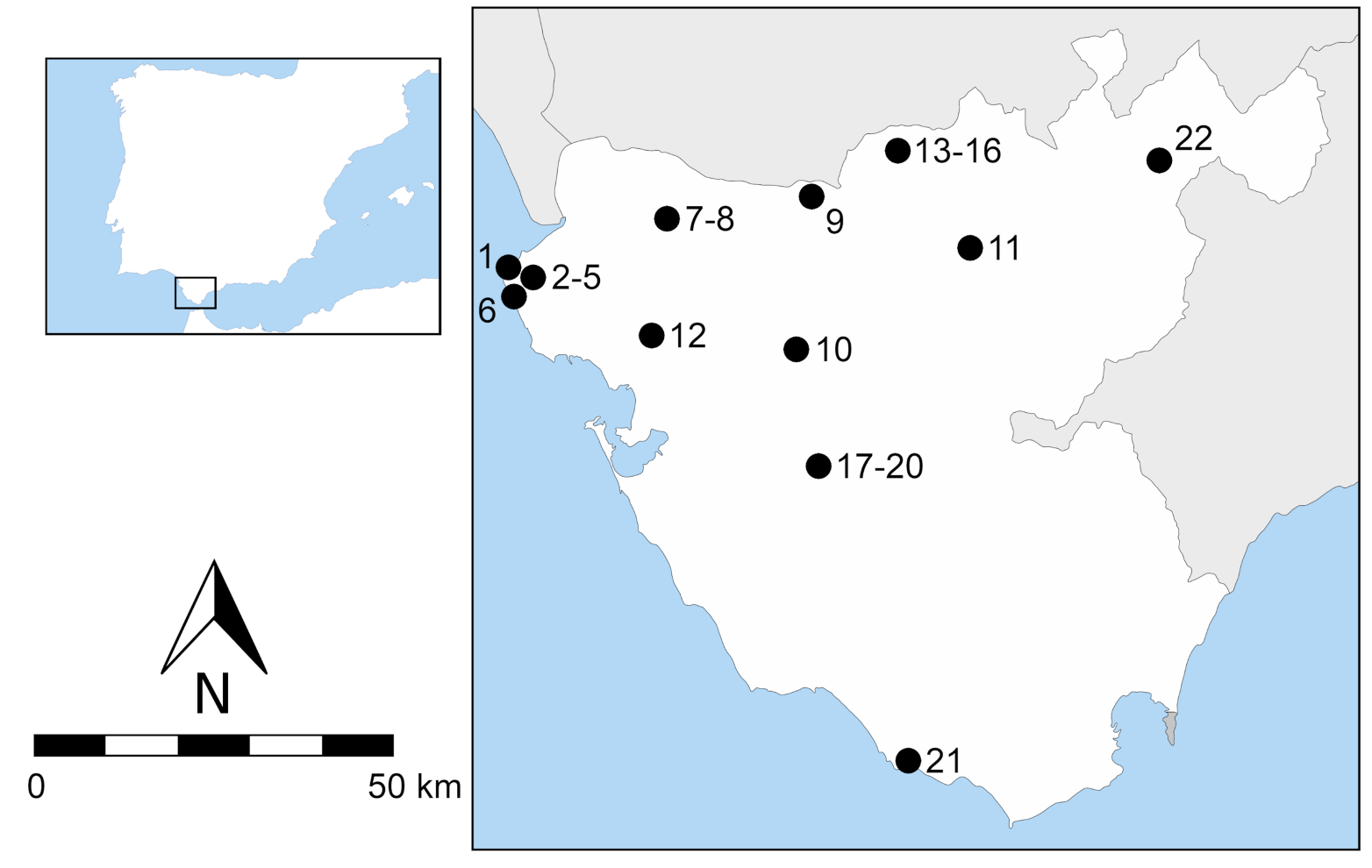

Figura 1. Mapa con los lugares de procedencia de los amuletos fálicos: 1. Regla (Chipiona). 2-5. Avenida de Sevilla, 86 (Chipiona). 6. Las Tres Piedras (Chipiona). 7-8. Mesas de Asta (Jerez de la Frontera). 9. Gibalbín (Jerez de la Frontera). 10. Vega del Torno (Jerez de la Frontera). 11. Cortijo Fuensanta (Arcos de la Frontera). 12. Sierra de San Cristóbal (El Puerto de Santa María). 13-16. Esperilla (Espera). 17-20. Asido Caesarina (Medina Sidonia). 21. Baelo Claudia (Tarifa). 22. ¿Cerro de la Botinera? (Los Algodonales). (Fuente: Elaboración propia). 
En cuanto a su clasificación tipológica, se emplea aquí la realizada por Del Hoyo y Vázquez Hoys (1996), aunque como se verá posteriormente se propone ampliar dicha clasificación con un amuleto fálico 'en pelta' hasta ahora ausente de todas las clasificaciones previas y del que se conocen algunos paralelos en el mundo galorromano.

\section{Amuletos fálicos}

\subsection{Regla (Chipiona)}

Pieza 1. Amuleto fálico doble de $1 \mathrm{~cm}$ de longitud realizado en oro (Figuras 2 y 3.1). Presenta una argolla central circular bajo la que se ha representado a la derecha un pene erecto con el glande sobresaliendo de la piel en forma cónica y a la izquierda una higa. Se conserva actualmente en el Castillo de Chipiona sin número de inventario.

Su hallazgo se produjo en las inmediaciones del santuario de Nuestra Señora de Regla. El lugar se caracteriza por formar un pequeño promontorio natural que domina un amplio ancón que se extendía desde la Punta de Camarón hasta la del Perro, siendo la única zona sin plataforma rocosa en todo el término municipal. Por este motivo, la zona estaba conformada por cordones dunares de arenas voladeras, por lo que la visualización superficial de cualquier tipo de vestigio se presentaba prácticamente imposible. A este problema le sustituyó la pronta urbanización del lugar, lo que imposibilita, al menos desde principios del siglo XX, el reconocimiento del terreno.
Hasta hace pocas décadas se conocían únicamente en la zona testimonios escritos sobre los hallazgos fortuitos producidos desde mediados del siglo XVII, haciéndose alusión casi en la totalidad de ellos a la aparición de numerosos enterramientos, en su mayoría de época romana (Alcázar et al., 1994: 36-47; Aracil y Martínez, 1909; Carmona, 1635-39: 248; Madrazo, 1884: 191), a excepción de dos sepulturas púnicas (Fernández-Chicarro, 1962: 67; Tejera, 1979: 149). Entre los hallazgos documentados hay que destacar varias lápidas funerarias con epigrafía (González, 1982: 57-58; Vives, 1942: 45-46) y un vaso de terra sigillata gálica de la forma 37 de Dragendorff (Martínez, 1949). De igual manera se han constatado varias esculturas marmóreas: una cabeza de Venus (Anónimo, 1867: 231) y otras dos de difícil identificación, aunque fechadas entre los siglos I y II d.C. (Gómez y Rodríguez, 2014: 150).

También se tienen noticias de hallazgos de varias piezas metálicas encontradas por Bartolomé Junquero, vecino de Chipiona, procedentes de pozos conocidos en las inmediaciones de Regla entre finales del siglo XIX y principios del XX. Entre estos objetos se citan un Príapo alado (Engel, 1900: 70), un anillo de plata con grabado de connotación sexual, dos amuletos fálicos de oro de un centímetro de longitud con anilla para colgarlo y otro de bronce (Romero de Torres, 1934: 195). De estas piezas no se tiene más información. No obstante, tras la publicación en estas páginas de cinco amuletos fálicos procedentes de Regla y sus inmediaciones,

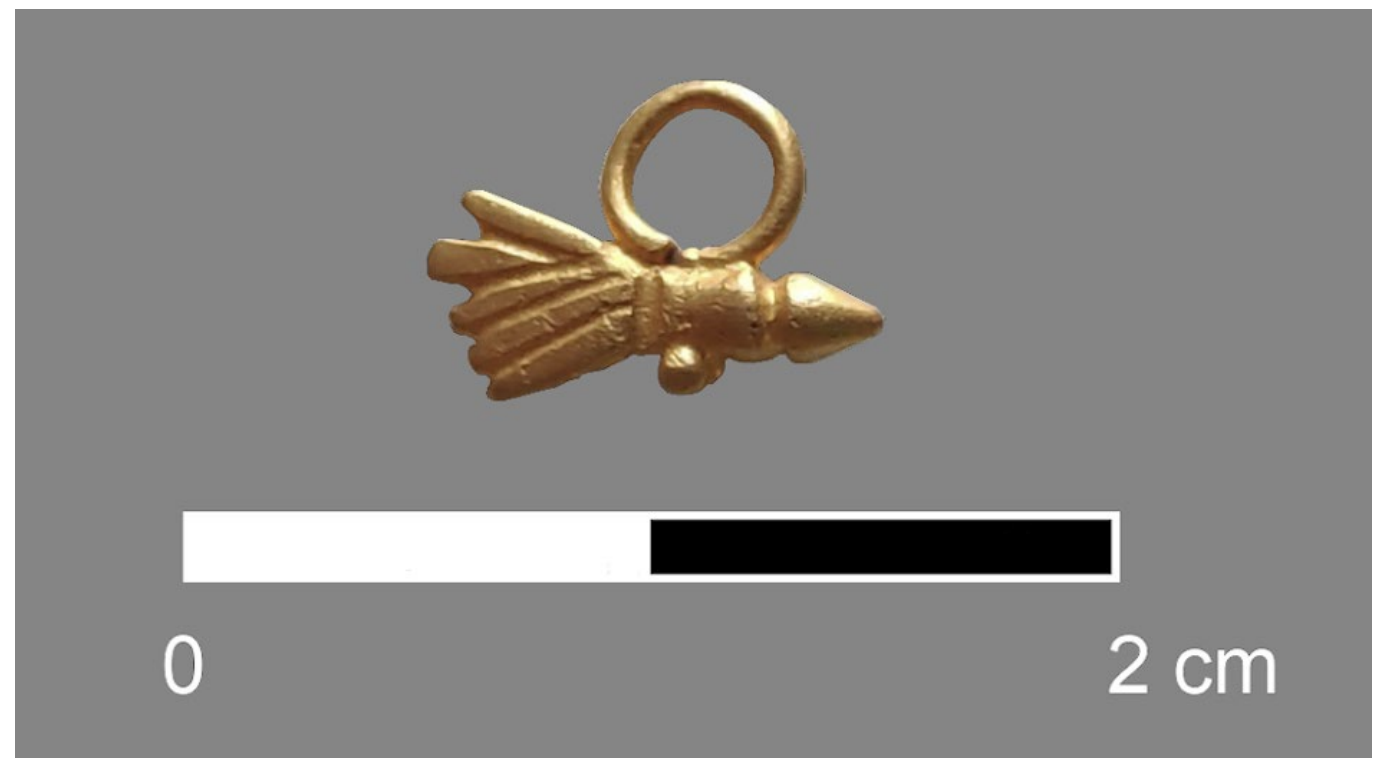

Figura 2. Amuleto fálico de oro proveniente de las inmediaciones del santuario de Nuestra Señora de Regla (Chipiona, Cádiz). (Fuente: Elaboración propia). 

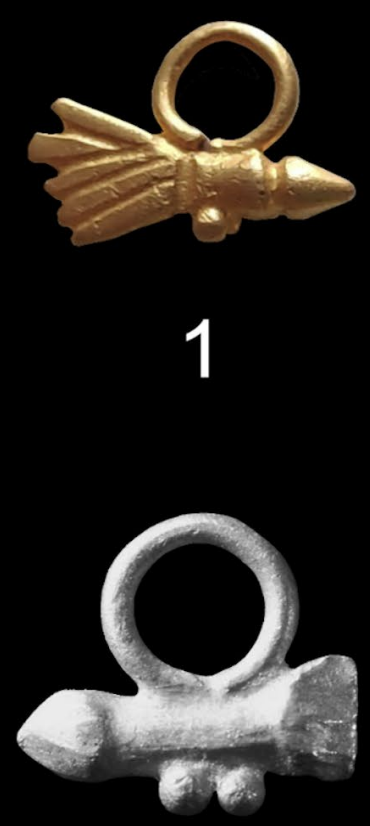

3

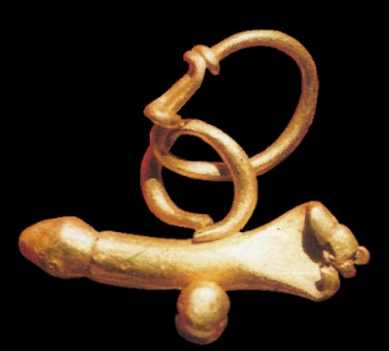

5

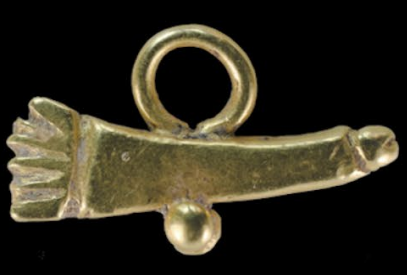

7
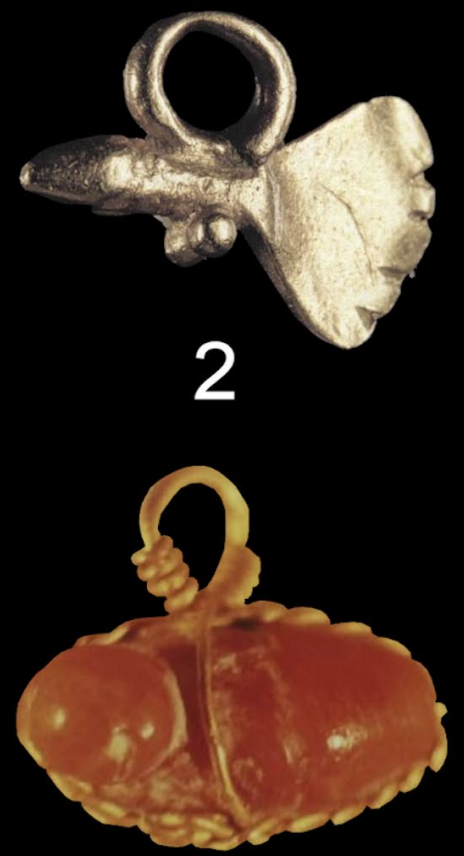

4

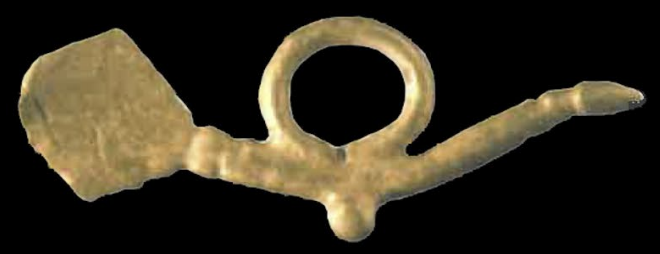

6

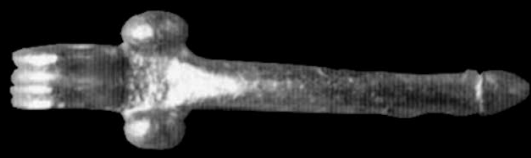

8

Figura 3. Amuletos fálicos de oro localizados en la península Ibérica: 1. Regla (Chipiona, Cádiz) (elaboración propia). 2. Las Amoladeras (Cartagena, Murcia) (a partir de Miñano, 2006: 10). 3. Bilbilis (Calatayud, Zaragoza) (a partir de Sáenz y Lasuén, 2004: 227). 4. Segobriga (Saelices, Cuenca) (a partir de Almagro y Abascal, 1999: 148). 5. Iruña-Veleia (Iruña de Oca, Álava) (a partir de Gil, 1994: 58). 6. Libisosa (Lezuza, Albacete) (a partir de Poveda, 2009: 170). 7. Los Bañales (Uncastillo, Zaragoza) (a partir de Andreu y Urrizburu, 2019: 323). 8. Braintree (Essex, Inglaterra) (a partir de Johns y Wise, 2003: 274) (los amuletos han sido reproducidos sin guardar correspondencia de escala entre ellos). 
entre los cuales se encuentra un ejemplar alado, no habría que descartar que esta noticia sobre un Príapo igualmente alado fuera una manera elegante de hacer referencia a una pieza como las aquí analizadas, toda vez que la mención explícita a un falo pudo haber sido evitada por pudor.

Por lo que respecta a las intervenciones arqueológicas, hasta el momento se han realizado en este enclave dos excavaciones preventivas y dos puntuales.

La primera de ellas, practicada en 1991, dio como resultado la aparición de una necrópolis romana exclusivamente infantil datada entre los siglos III y IV d.C., la cual amortizaba un edificio fechado a mediados del siglo I d.C. (Alcázar et al., 1994: 36-47). En 2009 se localizaron varias estructuras muy arrasadas, entre las que figuraba una pileta, al igual que en la anterior excavación, y un basurero con abundante material cerámico (Barreiro, 2009).

En el año 2015 se llevó a cabo una actividad arqueológica puntual que conllevó la realización de un sondeo de $25 \mathrm{~m}^{2}$ en la Plaza del Humilladero. Esta excavación fue ampliada en 2018 a $125 \mathrm{~m}^{2}$ con motivo de la creación de un centro cultural arqueológico por parte del consistorio municipal. Los resultados de dichas actividades fueron notablemente fructíferos, permitiendo establecer la existencia de una secuencia estratigráfica que, sin clara solución de continuidad, presentaba en su inicio estructuras funerarias datadas entre los siglos IV-VII d.C. (Rodríguez et al., 2018).

Todos estos descubrimientos reflejan el uso continuado en el tiempo de la zona de Regla como espacio funerario en época romana desde, al menos, el siglo I d.C. hasta el VII d.C. Esta información nos hace proponer, a pesar de no contar con datos para precisar más su contexto arqueológico, que el presente ejemplar pudo haber sido depositado en una tumba de época romana altoimperial o tardoantigua en las inmediaciones del santuario de Nuestra Señora de Regla.

Por otra parte, el hecho de estar realizado en oro le aporta a esta pieza un carácter de exclusividad que se ve refrendado por el escasísimo número de ejemplares documentados en este material tanto dentro como fuera de la península Ibérica. Un repaso por ellos permite comprobar que en la gran mayoría de las ocasiones su tipología y detalles son muy semejantes, por lo que parece que su producción estuvo bastante estandarizada.

El primero de los paralelos aquí analizados pro- cede del yacimiento de las Amoladeras (Cartagena, Murcia) (Figura 3.2), ubicado frente a la playa del mismo nombre, cerca del cabo de Palos. En este lugar se halló un pecio datado en torno al siglo I a.C. entre cuyos restos se documentaron fragmentos de ánforas y cerámica común, piezas de plomo con gran cantidad de glandes de este mismo material, fístulas, piezas de ensamblar y un colgante fálico de oro depositado actualmente en el Museo Nacional de Arqueología Marítima (Cartagena, Murcia) (no inv. 50275) (Mas, 1985: 162; Miñano, 2006: 8-14 ; Parker, 1992: 54, no 39).

Otro paralelo de gran similitud es el amuleto fálico de oro procedente de algún lugar indeterminado de Bilbilis (Calatayud, Zaragoza) (Figura 3.3) y actualmente depositado en el Museo de Calatayud ( $\mathrm{n}$ - inv. 426). Al igual que la pieza de Regla, se trata de un ejemplar de tipología doble con falo enhiesto, higa sin sus dedos detallados de modo individual y testículos en la zona central. Debido a que el diámetro de su anilla es bastante reducido, Sáenz y Lasuén (2004: 225) han propuesto que este amuleto podría haberse utilizado como pendiente, en vez de como colgante.

Un tercer ejemplar es el amuleto fálico facturado en oro y coral de Segobriga (Saelices, Cuenca) (Figura 3.4) (Almagro y Abascal, 1999: 148, fig. 103; Almagro y Lorrio, 1989: 241), cuyos materiales han sido puestos en relación con el probable alto estatus social de su poseedor (Almagro y Abascal, 1999: 148).

De Iruña-Veleia procede otro ejemplo áureo que presenta una sección circular con los testículos esféricos y una anilla (Filloy, 1997: 785 y 795; Gil, 1994: 58; Sáenz y Lasuén, 2004: 225) (Figura 3.5). El yacimiento de Iruña-Veleia fue uno de los asentamientos romanos más importantes del norte de la península Ibérica, fruto de lo cual desarrolló un urbanismo de gran relevancia con destacadas construcciones arquitectónicas hasta su abandono durante la tardoantigüedad (Gil, 1994: 58).

Procedente de Libisosa, Lezuza (Albacete), se tiene constancia de un pequeño amuleto fálico de oro sin contexto asociado conocido. Mide 1,8 cm de longitud máxima, ha sido fechado entre los siglos I a.C. y I d.C., y se encuentra actualmente depositado en el Museo Arqueológico Municipal de Elda (Figura 3.6) (Poveda, 2009: 170).

En el yacimiento de Los Bañales, Uncastillo (Zaragoza), se ha encontrado otro colgante fálico de oro de pequeñas dimensiones (Figura 3.7). Su hallazgo se produjo en 2018 al interior de una de 
las estancias en que quedó compartimentado un edificio público que monumentalizaba el barrio norte de esta ciudad romana. La fecha dada a la amortización del nivel de aparición de esta pieza se sitúa en torno a la segunda mitad del siglo II d.C., si bien los arqueólogos que han publicado este amuleto no descartan que pudiera haberse utilizado durante el siglo I d.C. (Andreu y Urrizburu, 2019: 322-325).

Fuera de la península Ibérica se conocen también ejemplares fabricados en oro. Es el caso de un amuleto de pequeñas dimensiones encontrado por un particular en Braintree (Essex, Inglaterra) (Figura 3.8) que ha venido siendo datado en torno al siglo IV d.C. (Johns y Wise, 2003: 274-276).

Igualmente, procedentes de Roma se conocen tres piezas realizadas en oro con representaciones fálicas. La primera de ellas se trata de un amuleto áureo datado en el siglo II d.C. en el que se han representado un lagarto y una serpiente lanzándose sobre un ojo. Esta pieza, citada por Alvar Nuño en su monografía, formó parte de la exposición 'Memorie del Sottosuolo', realizada en la capital italiana en 2007, pero no se incluyó en el catálogo (Alvar, 2010: 166 y 317). Las dos restantes son sendos anillos de oro con un pene grabado en su superficie del s. I d.C. y conservados actualmente en la Colección Fortnum del Ashmolean Museum de Oxford (Inglaterra) (Alvar, 2010: 238 y 313; Hening y McGregor, 2004, figs. 6.7 y 6.8).

\subsection{Avenida de Sevilla, 86 (Chipiona)}

Pieza 2. Amuleto fálico simple de 4,1 cm de longitud sin argolla ni testículos. Realizado en bronce (Figura 4.1).

Pieza 3. Amuleto fálico simple de $3,4 \mathrm{~cm}$ sin testículos ni argolla de suspensión (Figura 4.2).

Pieza 4. Amuleto fálico simple sin argolla ni testículos fabricado en bronce de 3,5 cm (Figura 4.3).

Pieza 5. Amuleto fálico alado de bronce de 3,1 cm de longitud (Figura 4.4).

En 2009 se llevó a cabo una actividad arqueológica preventiva ejecutada por Barreiro Espinal en el solar sito en Avenida de Sevilla no 86 de Chipiona. Hay que remarcar que este lugar se encuentra a menos de 100 metros del Santuario de Nuestra Señora de Regla, donde se ha puesto de manifiesto el carácter funerario de la zona en época romana y tardoantigua. En dicha intervención se localizaron varias estructuras muy arrasadas correspondientes a dos horizontes cronoculturales distin- tos (Barreiro, 2009). De una parte, restos islámicos. De otra, actividad antrópica de época romana. Tras el desmonte de los primeros, a -0,40 m se documentó un estrato de arenas claras que ocupaba todo el solar, con una potencia aproximada de $0,70 \mathrm{~m}$. En él se localizaron un vertedero/escombrera y varias estructuras que profundizaban hasta $-1,18 \mathrm{~m}$, cota a la que aparecieron arenas rubias estériles.

El vertedero se situaba en una duna y parece ser que se colmató poco tiempo después de su creación, en el siglo I d.C. En él se documentaron fragmentos de tégulas, restos de opus signinum, fragmentos de terra sigillata, cerámica común, fragmentos de ánforas, anzuelos, agujas para coser redes, plomos, vidrio, dos monedas de bronce y clavos del mismo metal. Se pudo comprobar que dicha escombrera continuaba en la parcela contigua, actualmente edificada. Tras esta intervención, vecinos de la localidad llevaron a cabo la búsqueda de restos arqueológicos en la terrera resultante del desmonte de dicho vertedero, encontrando las piezas aquí indicadas.

Debido a los hallazgos arqueológicos, desde la Delegación Provincial de Cultura de Cádiz se instó a la realización de un sondeo de $4 \mathrm{~m} 2$ en el solar colindante con el fin de confirmar si en él también se daban los mismos hallazgos que en la intervención recién descrita de la parcela contigua. El sondeo se planteó en el centro del terreno, profundizándose hasta los $-3,30 \mathrm{~m}(4,50 \mathrm{~m}$ desde la cota 0 ). La secuencia estratigráfica del sondeo constató la continuidad de las arenas rubias estériles hasta llegar a un limo negro, momento en el que se cesó el rebaje del sondeo debido a la ausencia de restos arqueológicos.

Dados los pocos datos proporcionados por el inventario de materiales de dicha intervención, en el año 2012 se realizó un estudio y revisión de los mismos para conocer mejor las tipologías halladas y su cronología. Los resultados de dicho estudio permitieron proponer la existencia de dos conjuntos bien diferenciados, uno situado en el cambio de era (ca. 15 a.C.-15 d.C.), bien representado por las sigillatas itálicas, las ánforas ovoides (muy cercanas tipológicamente a las Dressel 7-11) y diversas Haltern 70, y otro grupo que corresponde al grueso del material estudiado, comprendido aproximadamente entre el 25 y el 60 d.C. (Herrera y Rodríguez, 2014; Rodríguez, 2017: 90-101).

En cuanto a la tipología de estos amuletos, tras un primer análisis de las piezas, los firmantes del presente estudio consideramos que los ejem- 


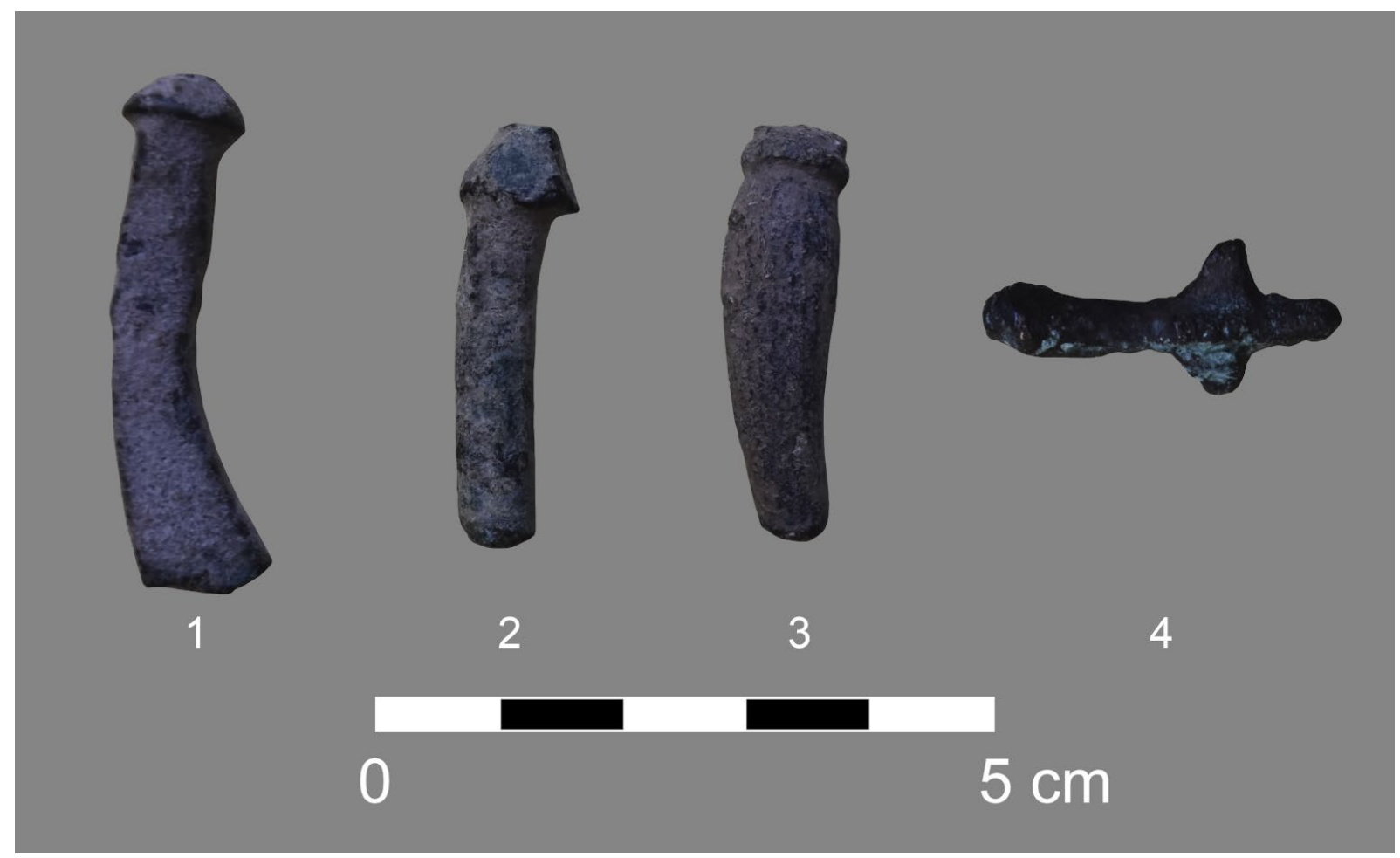

Figura 4. 1-3. Amuletos fálicos simples sin testículos localizados en Avenida de Sevilla, 86 (Chipiona). 4. Amuleto fálico alado hallado en Avenida de Sevilla, 86 (Chipiona). (Fuente: Elaboración propia).

plares 2, 3 y 4 eran clavos de época romana algo desfigurados, asunto que cuadraba perfectamente con algunas de las piezas documentadas durante la intervención arqueológica de Barreiro. No obstante, la forma redondeada y abultada en algunos puntos intermedios de sus cuerpos, diferente a la habitual sección cuadrangular que suelen presentar estos objetos, nos hizo dudar sobre si era correcta nuestra identificación. No fue hasta la consulta de la obra Sexo y erotismo: Roma en Hispania que tuvimos ocasión de comprobar la existencia de amuletos similares en otras partes de la península Ibérica sin presencia de testículos ni de argolla de suspensión (Vázquez, 2009: 54-55, lám. 5), motivo que nos ha llevado a incluir este lote dentro del presente conjunto. A ello hay que añadir la existencia de la pieza número 5 , procedente de la misma terrera.

En cuanto a su cronología, teniendo en cuenta las fechas indicadas anteriormente, el uso de los amuletos hallados en la escombrera de este yacimiento podría situarse ante quem al siglo I d.C.

\subsection{Las Tres Piedras (Chipiona)}

Pieza 6. Amuleto fálico triple de bronce de 5,4 $\mathrm{cm}$ de longitud (Figura 5). A la derecha se ha re- presentado un falo en erección que presenta dos líneas incisas bajo el glande. A la izquierda se observa una higa, aunque su mal estado de conservación no permite confirmar este detalle. En la zona central, el amuleto consta de una argolla para su suspensión y debajo de ella la típica imagen de un pene flácido junto a la bolsa escrotal. En esta ocasión, el pene no se ha conservado. Posiblemente sobre él se hayan grabado líneas en representación del vello púbico, si bien de nuevo el mal estado de conservación de la pieza no permite confirmar este aspecto. El amuleto fue dado a conocer previamente (Gómez y Rodríguez, 2013). Se conserva actualmente en el Castillo de Chipiona, sin número de inventario.

Este ejemplar se halló en la playa de Las Tres Piedras. El lugar del hallazgo ha sido poco estudiado debido fundamentalmente a las construcciones ilegales existentes, así como por tratarse de un sustrato dunar que oculta cualquier ápice de evidencia material, habiéndose producido buena parte de los descubrimientos de forma fortuita. Como es habitual con respecto a la inmensa mayoría de los amuletos fálicos que conocemos en la actualidad, su hallazgo se produjo fuera de contexto, por lo que carece de una relación estratigráfica que permita una datación aproximada. 


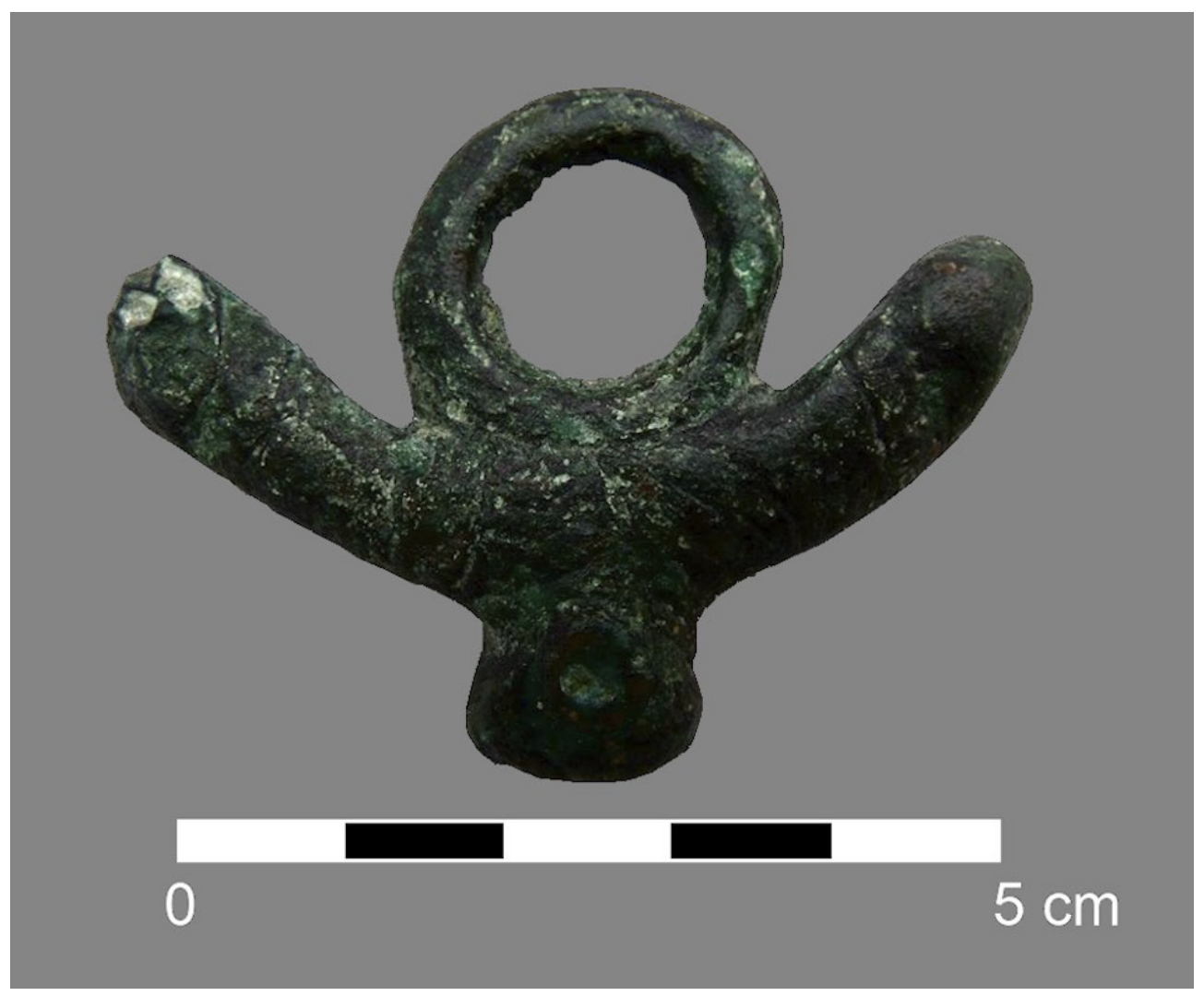

Figura 5. Amuleto fálico de bronce procedente de Las Tres Piedras (Chipiona, Cádiz). (Fuente: Elaboración propia).

\subsection{Mesas de Asta (Jerez de la Frontera, Cádiz)}

Pieza 7. Amuleto fálico triple, fracturado en su apéndice izquierdo, de $6 \mathrm{~cm}$ de longitud y realizado en bronce (Figura 6.1). Bajo la anilla central se ha elaborado mediante incisiones el vello púbico, un pene en reposo de pequeñas proporciones y la bolsa testicular. En su parte derecha presenta un pene en posición erecta. Es probable que, siguiendo el modelo habitual para estas piezas, en su extremo izquierdo hubiera sido moldeada una higa. La pieza ha sido publicada previamente de modo sucinto (Pozo, 2002: 91, cat. 48, con otro número de inventario; González y Barrionuevo, 2020: 93). Actualmente en el Museo Arqueológico de Jerez de la Frontera. №. inv. 573.

Pieza 8. Amuleto de bronce en forma 'de ruleta' de 6,5 cm de longitud (Figura 6.2). La pieza tiene en su zona central un agujero circular en el que presumiblemente habría estado inserto un pasador que habría permitido girar la pieza. A diferencia de los demás ejemplares, es posible que este tipo de amuleto no hubiera sido utilizado como colgante. En el extremo izquierdo se aprecia la representación de un falo erecto con la piel retraída dejando asomar el glande, mientras que en el otro apéndice se observa una mano con el puño cerrado y una posible pulsera colocada a la altura de la muñeca. La pieza ha sido publicada previamente con una sucinta descripción por Pozo (2002: 91, cat. 47). Se conserva en el Museo Arqueológico de Jerez de la Frontera. №. inv. 574.

Pocos enclaves dentro del suroeste de la península Ibérica han tenido la importancia de Hasta Regia en época romana. Dicho yacimiento se encuentra localizado en el actual barrio rural de Mesas de Asta, a once kilómetros en sentido noroeste del núcleo urbano de Jerez de la Frontera y quince kilómetros al sur de Lebrija. Las referencias textuales en época clásica sobre este asentamiento no solamente son numerosas, sino que reflejan la preponderancia política y económica que tuvo en el pasado. Algo similar ocurre con los hallazgos escultóricos y epigráficos, algunos de ellos conocidos desde antiguo (síntesis arqueológicas y filológicas de interés son las de González y Ruiz, 1999; González, 2011a; Ruiz et al., 2016: 39-74; Martín-Arroyo, 2018). A pesar de todo ello, no se realizaron excavaciones arqueológicas en el sitio hasta las décadas de los cuarenta y cincuenta del siglo XX de la 
mano de Esteve Guerrero, documentándose en sucesivas campañas, entre otros restos, lienzos de su muralla, edificios, un horno industrial y parte de una necrópolis de época imperial (Esteve, 1945, 1950, 1962, 1969).

Por lo que respecta a los amuletos fálicos, ambas piezas fueron entregadas al Museo Arqueológico de Jerez de la Frontera por Esteve Guerrero, probablemente como donaciones de varios campesinos de la zona al enterarse de sus labores en el yacimiento jerezano (Esteve, 1950: 35 y lám. XXX; 1962: 18 y lám. IX, fig. 1). A propósito de la segunda de las piezas aquí incluidas, el autor planteó que podría tratarse del mango de un puñal (Esteve, 1950: 35), reflejo del escaso conocimiento que se tenía sobre este tipo de piezas antes de la década de los ochenta.

\subsection{Gibalbín (Jerez de la Frontera)}

Pieza 9. Amuleto fálico triple de $5 \mathrm{~cm}$ de longitud elaborado en bronce (Figura 6.3). Su disposición es muy similar a la del primero de los objetos aquí descritos. Bajo la argolla central se ha representado de forma triangular el pubis con un pene en reposo. A la derecha nuevamente un pene erecto con el glande al descubierto. A la izquierda una higa. El ejemplar procede del cortijo La Mazmorra, en la Sierra de Gibalbín. Una imagen de esta pieza ha sido publicada previamente (González y Barrionuevo, 2020: 93). Actualmente está depositado en el Museo Arqueológico de Jerez de la Frontera. № inv. 1785.

La sierra de Gibalbín ha sido un enclave geográfico ocupado desde época neolítica hasta el presente. Todavía se conservan restos de unas termas, un arco monumental, estructuras revestidas con opus signinum posiblmente destinadas al almacenaminto de agua, una muralla de posible adscripción romana (Sillières, 1977: 342) y una torre de posible origen medieval que denotan la importancia del lugar, debido especialmente a sus excepcionales condiciones defensivas y de visibilidad. De entre los hallazgos más notables realizados en Gibalbín relativos al período romano hay que destacar varias inscripciones de carácter funerario (vid. González, 1982: 74-75), otra posiblemente también proveniente de Gibalbín donde se menciona su carácter municipal (González, 2014), una cabeza femenina de mármol (Romero de Torres, 1934: 120) y una escultura sedente de Pan sobre una roca (Luzón y León, 1971: 242).
A pesar de estos interesantes hallazgos, no se han realizado excavaciones en la zona para valorar en su justa medida el papel que jugó este yacimiento a lo largo de las diferentes etapas en que estuvo habitado. Mientras tanto, son varias las propuestas que se han realizado para tratar de averiguar la posible identidad del lugar. En las últimas décadas, algunos autores han visto en Gibalbín la ubicación idónea para la clásica Ceret a partir de datos numismáticos (Sáez y Blanco, 1996: 293), así como económicos y cartográficos (Montero, 2000: 8083, 2019: 68). Por su parte, otros investigadores han planteado lo mismo con el topónimo Cappa a partir de las menciones de Plinio (N.H. 3, 15) y el Anónimo de Rávena (A. Rav. 417: 5-7) (Chic, 19791980: 276; Tovar, 1974: 49). Más recientemente González Fernández ha barajado la posibilidad de que en este lugar se encontrase V(r)gia Castrum Iulium, a partir de la interpretación que hace de un fragmento de bronce presumiblemente procedente de Gibalbín con la inscripción MUN(icipium) V(giensis) (González, 2014).

\subsection{Vega del Torno (Jerez de la Frontera)}

Pieza 10. Amuleto fálico triple de bronce con una longitud máxima de $6,8 \mathrm{~cm}$ (Figura 6.4). La pieza, más desgastada que las anteriores, se distribuye de similar modo. La anilla central presenta en su zona inferior el pubis con un pene en reposo y la bolsa escrotal. A la derecha se encuentra un pene erecto y a la izquierda puede haberse representado bien una higa con el puño cerrado mostrando la palma de la mano hacia arriba o un pene igualmente erecto de menor grosor que el anterior. Unas estrías en diagonal separan los tres elementos que componen el colgante en su totalidad. Se conserva en el Museo Arqueológico de Jerez de la Frontera. № inv. 1924.

En las inmediaciones de la Vega del Torno se conoce la existencia de una villa romana asociada a restos de actividad alfarera (Chic, 19791980: 269-270; García et al., 2004; González y Ruiz, 1999; García, 2000: 176). El sitio ha sido denominado indistintamente como El Torno y Cementerio de San Isidro del Guadalete, siendo recientemente identificado con el empleo de ambos topónimos para evitar confusiones (García et al., 2004).

Debido al peligro de destrucción en que se encontraba este enclave, principalmente por la labor de las máquinas utilizadas en el vertedero que allí 


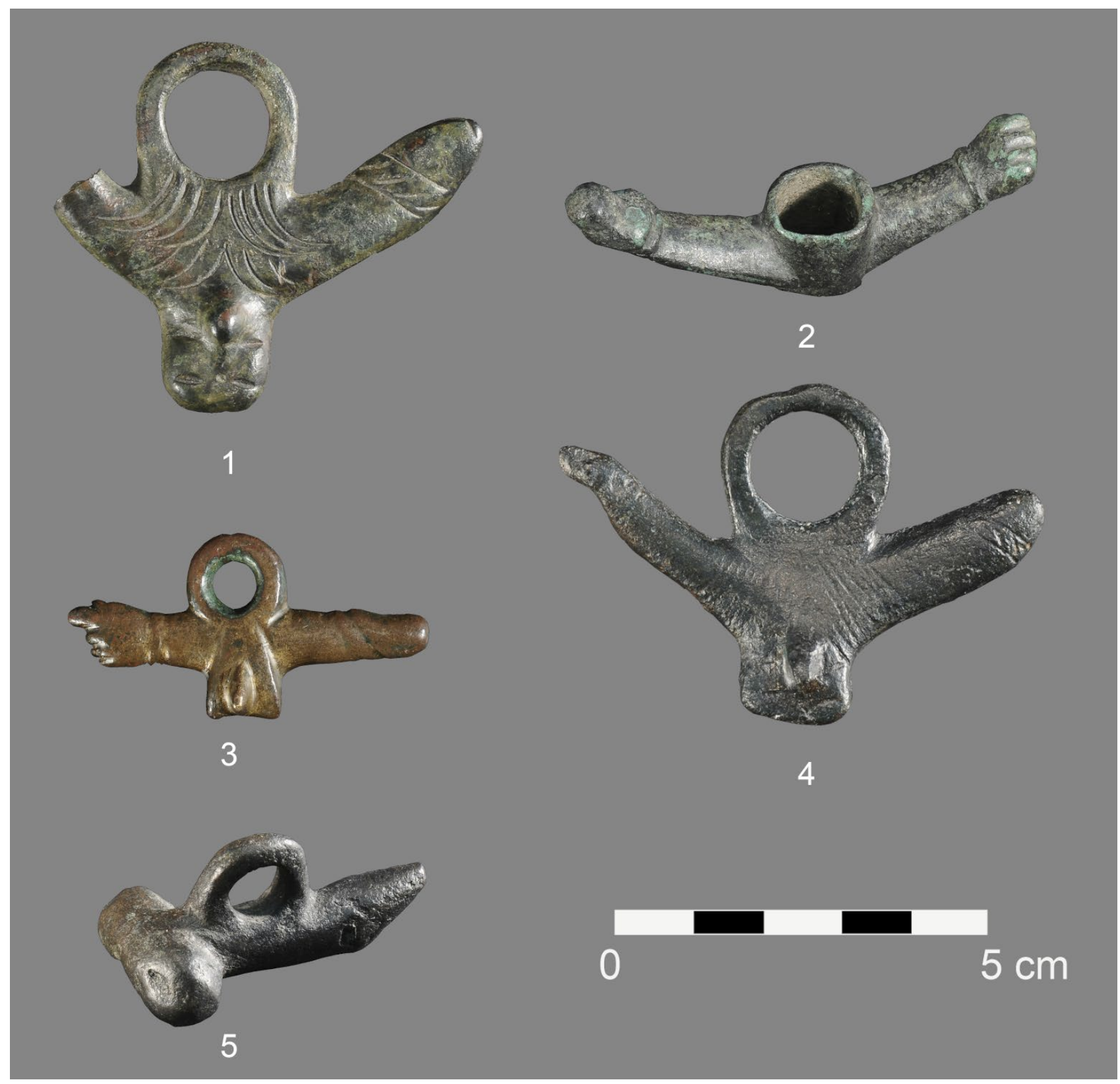

Figura 6. Amuletos fálicos depositados en el Museo Arqueológico de Jerez de la Frontera: 1. Amuleto fálico triple localizado en Mesas de Asta. 2. Amuleto en forma 'de ruleta' hallado en Mesas de Asta. 3. Amuleto fálico triple proveniente de Gibalbín. 4. Amuleto fálico triple procedente de Vega del Torno I. 5. Amuleto fálico simple de perfil hallado en Cortijo Fuensanta. (Fuente: a partir del Archivo Fotográfico del Museo Arqueológico de Jerez de la Frontera). 
se localiza, se realizó una intervención de urgencia en el año 2000. Con dicha excavación se documentaron restos de un vertedero perteneciente al testar del alfar con una producción mayoritaria de ánforas Dressel 7-11, Beltrán IIA, Beltrán IIB y restos de ocupación doméstica. Todo ello encuadrable entre el último tercio del siglo I d.C. y la primera mitad del siglo II d.C. (García et al., 2004).

\subsection{Cortijo Fuensanta (Arcos de la Frontera)}

Pieza 11. Amuleto fálico simple de perfil, facturado en bronce, de 4,7 cm de longitud (Figura 6.5). Se trata de una de las tipologías más sencillas de todas las conocidas. A la derecha de la argolla se encuentra representado el pene erecto con un acabado en punta. En la parte izquierda se han elaborado en paralelo los testículos. La pieza ha sido publicada previamente (Pozo, 2002: 90, cat. 40, con una breve descripción; González y Barrionuevo, 2020: 93) . Se encuentra en el Museo Arqueológico de Jerez de la Frontera. № inv. 575.

Fuensanta se sitúa en la loma del Membrillo, entre los arroyos del Hornillo y del Zánjar. Los trabajos previos en el entorno del cortijo han testimoniado la presencia de restos de época calcolítica, de la Edad del Bronce, de época romana e islámica (Perdigones, 1987; VV.AA., 2010: 538-544). De todas estas evidencias, se ha venido prestando mayor atención al asentamiento y al taller lítico de los primeros momentos de ocupación de este lugar, en el que predominan significativamente las láminas de talla a presión (Ramos et al., 1991a, 1991b, 1992: 11-12).

A medio kilómetro del cortijo, en la vertiente norte de la loma del Membrillo, se encuentra la Ermita de Fuensanta, construida en el siglo XVI. Este edificio da nombre al yacimiento arqueológico allí localizado, cuya cercanía con respecto al anterior permiten ponerlos en relación. En él se han identificado piezas de sílex datables en época epipaleolítica/neolítica, cerámicas y elementos constructivos del período romano, así como de épocas moderna y contemporánea. El sitio ha sido tradicionalmente relacionado con la ocupación musulmana, identificándose como lugar "santo" durante la conquista cristiana. No es por tanto descartable que este enclave fuese considerado un lugar de culto en momentos anteriores a la edificación de la ermita, dado que podrían haberse empleado para su construcción elementos constructivos de época visigoda (VV.AA., 2010: 545-552).

\subsection{Sierra de San Cristóbal (El Puerto de Santa María)}

Pieza 12. Amuleto fálico simple de perfil, realizado en bronce, de 2,3 cm de longitud (Figura 7). Ingresó en 1983 en el Museo Municipal de El Puerto de Santa María como donación particular de José Luis Villar. № inv. 344. La información procedente de esta institución portuense lo hace provenir de la Sierra de San Cristóbal, aunque no especifica yacimiento ni contexto concretos.

A diferencia de lo que ocurrió en otros períodos, la Sierra de San Cristóbal no fue una zona con una intensa ocupación en época romana. No obstante, se conocen varios asentamientos rurales de pequeñas dimensiones en sus inmediaciones de los que podría proceder el amuleto fálico. Entre ellos se encuentra Las Leonas, lugar ubicado al pie del Castillo de Doña Blanca, junto al manantial de La Piedad, donde se ha constatado la existencia de una posible villa con su alfar todavía visible en los años ochenta del siglo XX; otro yacimiento romano inmediatamente al norte de Las Leonas es la necrópolis de La Dehesa, en el que se han documentado dos enterramientos fechados entre los siglos III-IV d.C. sin ajuar asociado. El primero se trata de la incineración de un adolescente depositado en el interior de un dolium y el segundo de la inhumación de un adulto cubierto con lajas de piedra, tégulas e ímbrices. Muy cerca de allí aparecieron también en 1756 otras cinco tumbas posiblemente de la misma cronología; algo más al sur de la Sierra se encuentra el yacimiento de Buenavista, una modesta villa con alfar datable entre los siglos II a.C. y I d.C.; en la ladera sureste de San Cristóbal se encuentra el yacimiento de San Ignacio, un lugar con restos edilicios y posibles hornos alfareros fechable entre los siglos I y II d.C.; además de estos enclaves, existen otros pequeños núcleos rurales cuya funcionalidad se desconoce (López y Pérez, 2013: 37-40).

\subsection{Esperilla (Espera)}

Pieza 13. Amuleto fálico triple de bronce con una longitud máxima de $8,3 \mathrm{~cm}$ (Figura 8.1). Al igual que el resto de piezas, es probable que ésta proceda también de Esperilla. Actualmente en el Museo Arqueológico Municipal de Espera. № inv. 207.

Pieza 14. Amuleto fálico simple de perfil, de bronce de 4,7 cm de longitud (Figura 8.2). Al igual 


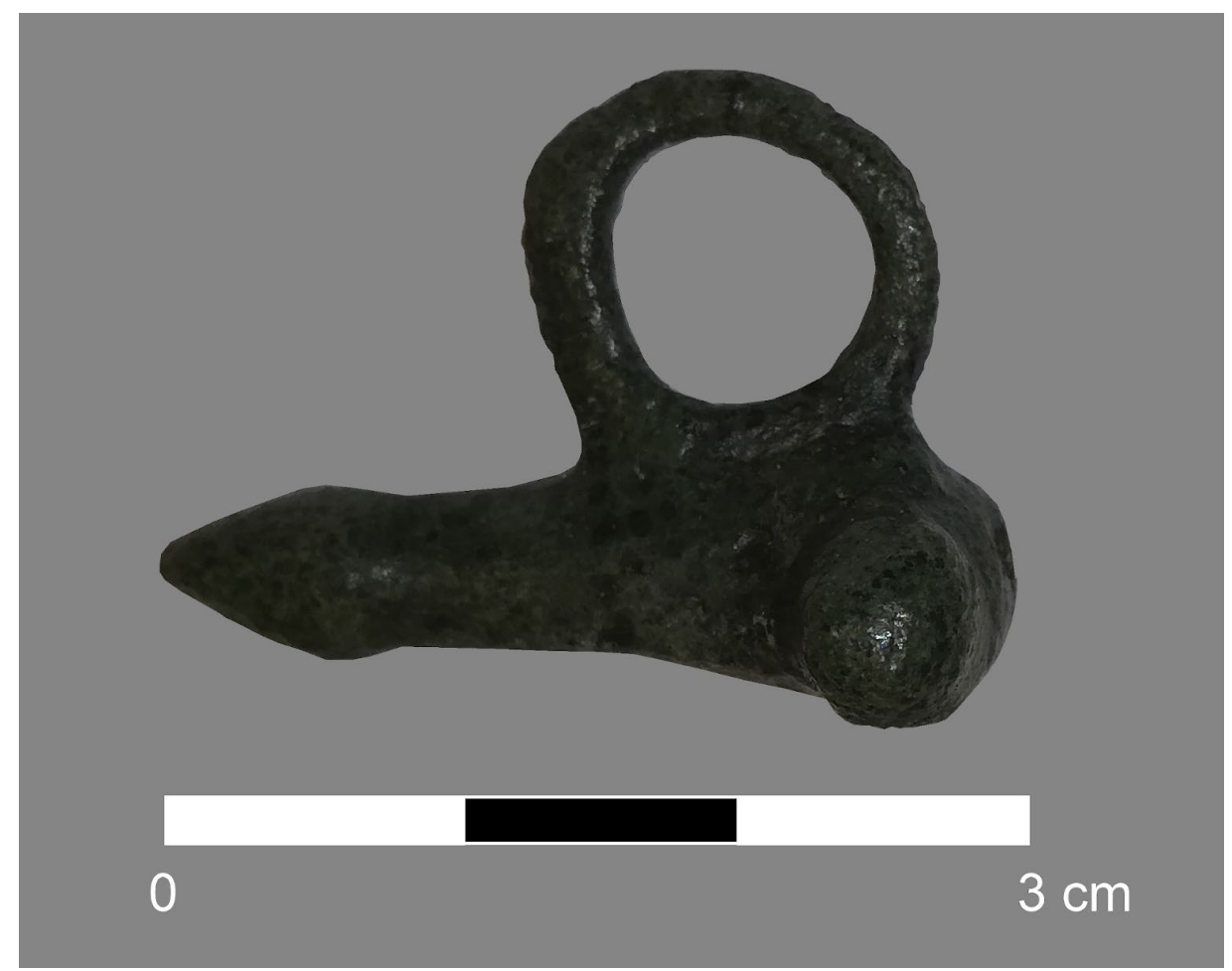

Figura 7. Amuleto fálico simple de perfil localizado en Las Cumbres. (Fuente: a partir del Archivo Fotográfico del Museo Local de El Puerto de Santa María).

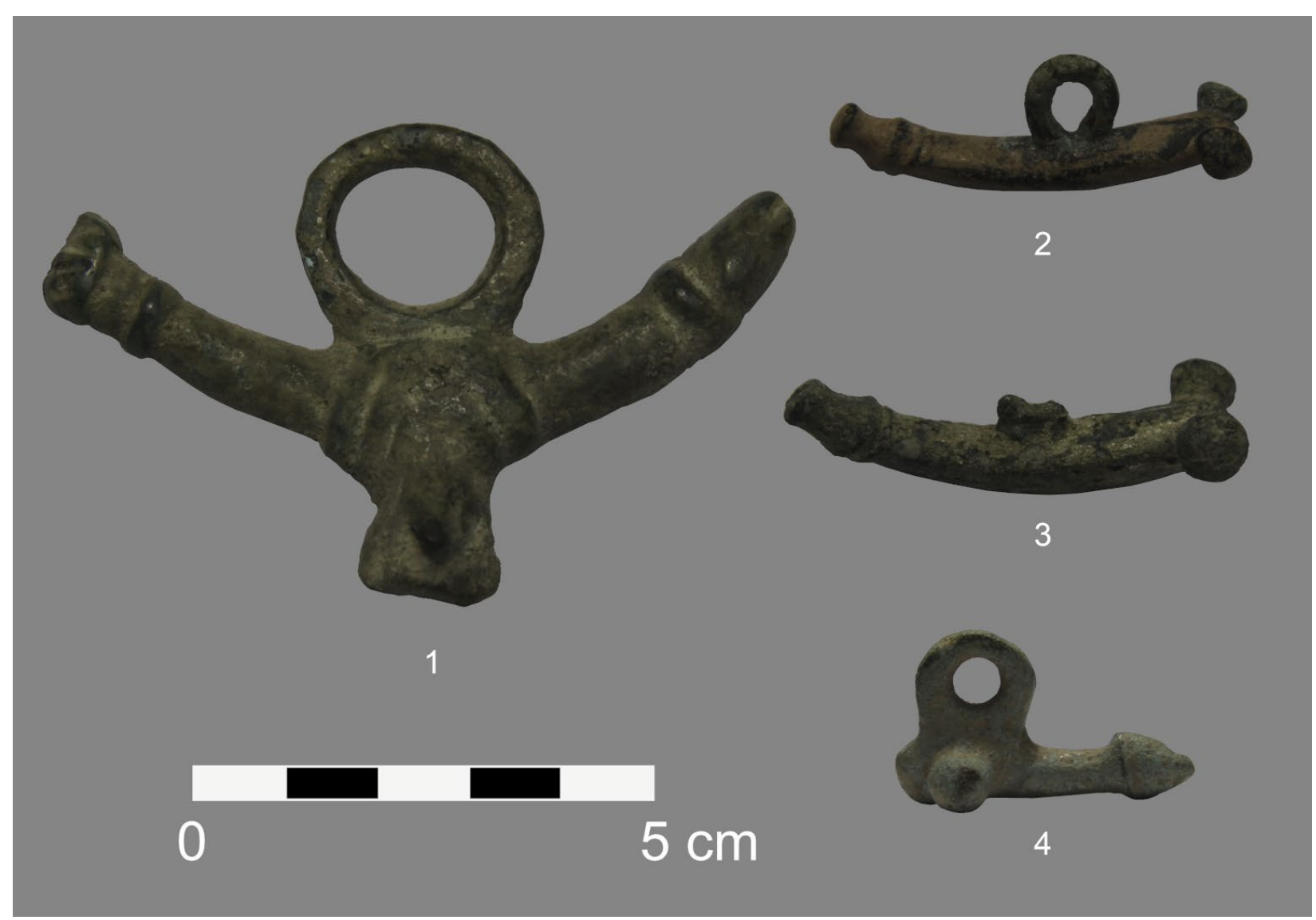

Figura 8. Amuletos fálicos procedentes de Esperilla: 1. Amuleto fálico triple. 2. Amuleto fálico simple en martillo. 3. Amuleto fálico simple en martillo. 4. Amuleto fálico simple de perfil proveniente de Esperilla. (Fuente: Elaboración propia). 
que el anterior, este ejemplar probablemente proviene de la necrópolis de Esperilla. Museo Arqueológico Municipal de Espera. № inv. 208.

Pieza 15. Amuleto fálico simple de perfil, hecho también en bronce, de 4,8 cm de longitud (Figura 8.3). Esta pieza es prácticamente idéntica a la anterior en todos sus detalles, a excepción de que es ligeramente más gruesa y alargada. No conserva la argolla de suspensión por rotura. Probablemente también se hallase en la necrópolis romana de Esperilla. Se encuentra en el Museo Arqueológico Municipal de Espera. № inv. 209.

Pieza 16. Amuleto fálico simple de perfil, realizado en bronce, de 3,2 cm de longitud (Figura 8.4). La pieza procede probablemente de la necrópolis de Esperilla. En la actualidad se halla depositada en el Museo Arqueológico Municipal de Espera. № inv. 210.

Esperilla se trata de uno de los yacimientos más emblemáticos de la sierra gaditana, próximo al emplazamiento de Carissa Aurelia. Asentamiento ubicado un kilómetro al norte del núcleo urbano de Espera y muy cerca del arroyo Salado, dominaba desde allí visualmente toda la comarca. En él se han documentado evidencias de ocupación neolítica, prestándosele una atención especial a la cerámica con decoración cardial (Gutiérrez et al., 1995); elementos calcolíticos, entre ellos un ídolo (Hurtado y Perdigones, 1983: 51-52, fig. 6); así como evidencias protohistóricas y romanas. Con respecto a este último período hay que citar la excavación de urgencia en 1989 de una tumba del siglo II d.C. (Perdigones et al., 1991). Sin embargo, los restos más emblemáticos del yacimiento se tratan de esculturas de carácter funerario, principalmente con forma leonina, emparentables con otras procedentes del sureste de la península Ibérica (Pérez, 1999: 62-73). Quizás puedan vincularse los hallazgos puntuales de estos amuletos con contextos funerarios similares al acabado de mencionar, como ya se ha visto para el caso de Chipiona.

\subsection{Asido Caesarina (Medina Sidonia)}

Pieza 17. Amuleto fálico simple en forma de martillo, facturado en bronce, de 4,1 cm de longitud (Figura 9.1). Procede de algún lugar indeterminado de Medina Sidonia. Al igual que el resto de piezas del presente apartado se encuentra en el Museo Arqueológico de esta localidad pendiente de número de registro de entrada.

Pieza 18. Amuleto fálico triple realizado en bronce de 6,5 cm de longitud. En su parte derecha muestra la representación del pene erecto, a la izquierda la higa y en el centro debajo de la argolla de suspensión tiene la bolsa escrotal y el pene en reposo característico de este tipo de ejemplares (Figura 9.2). Procede de algún lugar indeterminado de Medina Sidonia. № inv. D.176.

Pieza 19. Amuleto fálico triple de bronce. Se encuentra fracturado en su apéndice derecho. En su extremo izquierdo muestra un falo con los pliegues de la piel recogidos bajo el glande y en el centro un pene flácido junto a la bolsa escrotal. En la zona superior conserva la argolla. Es probable que, en esta ocasión, el amuleto tuviera colocada a la derecha la higa (Figura 9.3). Procede de algún lugar indeterminado de Medina Sidonia. № inv. D.105.

Pieza 20. Amuleto fálico en forma de lúnula o de pelta. En la zona superior preserva parte de la argolla de suspensión fracturada. Debajo de ella, en el centro, se observa un falo erecto estilizado. A los lados, la pieza se curva terminando en dos pequeñas puntas redondeadas (Figura 9.4). Procede de algún lugar indeterminado de Medina Sidonia. № inv. D.110. Debido a que la forma que presenta la pieza es bastante infrecuente entre los amuletos fálicos romanos, que tiene su superficie especialmente lisa y que no presenta detalles decorativos en el falo, barajamos en un primer momento la posibilidad de que se tratase de un pinjante fálico en forma de pelta de época cristiana. Piezas con forma de pelta, realizadas igualmente en bronce, solían colocarse como elementos apotropaicos sobre los cuartos traseros y delanteros de los caballos. No obstante, no hemos localizado entre la bibliografía consultada ningún pinjante de época medieval o moderna que lleve asociadas la pelta y el falo. Sí encontramos, por el contrario, un paralelo estrecho para este ejemplar procedente de una tumba de época tardorromana que contenía los restos de un niño de diez años en el yacimiento de Arras (Francia) (Dasen, 2003: 284-285, lám. IV, fig. 9; Jelski, 1984: 263, lám. 1, 7) (Figura 10). Por este motivo, aunque creemos que se trata de una tipología de amuleto fálico hasta el momento inédita en la Bética, resulta más probable aceptar una adscripción cronológica romana, en consonancia con el resto de amuletos depositados en el Museo Arqueológico de Medina Sidonia.

El término municipal de Medina Sidonia cuenta con un rico patrimonio romano procedente del primitivo asentamiento conocido en la antigüe- 
dad como Asido Caesarina, topónimo con el que el nombre de la localidad y su gentilicio todavía conserva un claro nexo lingüístico. Al igual que ocurre con el caso de Hasta Regia, existen numerosas referencias a este antiguo enclave romano a partir de epígrafes y leyendas monetales documentados tanto dentro como fuera de la propia Medina Sidonia (para síntesis recientes sobre Asido con bibliografía asociada vid. Lagóstena, 2011; González, 2011b).

La ubicación exacta de esta colonia romana se encuentra debajo del actual casco histórico de la localidad, como así se desprende de los hallazgos arqueológicos realizados en las últimas décadas en el subsuelo asidonense. Gracias a ellos se ha podido conocer un desarrollo urbanístico importante, especialmente para el caso de la Asido altoimperial, con la constatación entre otros contextos de un castellum, un tramo de pavimento del posible cardus maximus de la colonia, así como parte de la red hidráulica del municipio junto a restos de viviendas y criptopórticos (Montañés, 1993, 1995, 1998; Montañés y Aguilera, 2002a, 2002b; Mon- tañés y Montañés, 2006, 2009a, 2009b). Junto a estos descubrimientos, y en consonancia con la importancia de estas estructuras públicas, se han recuperado dentro del término municipal de Medina Sidonia varias esculturas de mármol recientemente estudiadas en su conjunto (Beltrán et al., 2018).

No obstante, a pesar de todas estas intervenciones y hallazgos, se desconoce la procedencia exacta de los amuletos fálicos aquí presentados, fruto de donaciones realizadas por vecinos de la localidad.

\subsection{Baelo Claudia (Tarifa)}

Pieza 21. Amuleto fálico 'de ruleta' realizado en bronce de 5,1 cm de longitud (Figura 11). Procede del antiguamente denominado sector IV de Baelo Claudia, aunque sin ubicación concreta, y fue dado a conocer previamente (Dardaine et al., 1979: 554-555, fig. 11, 1). Actualmente se encuentra depositado en el Conjunto Arqueológico de Baelo Claudia. № inv. 78.5185.

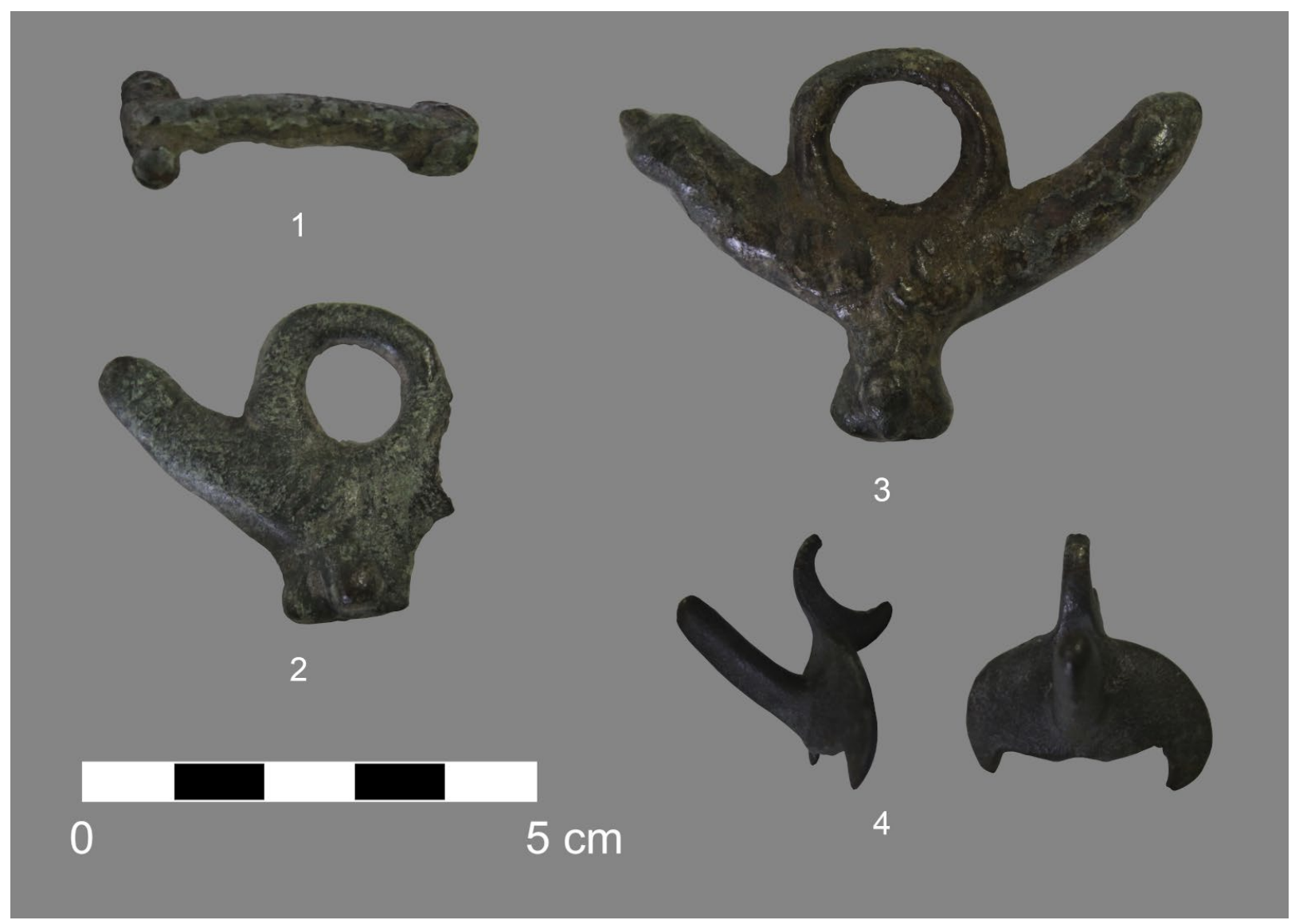

Figura 9. Amuletos fálicos provenientes de Medina Sidonia: 1. Amuleto fálico simple en martillo. 2. Amuleto fálico triple. 3. Amuleto fálico triple fracturado. 4. Amuleto fálico 'en pelta'. 

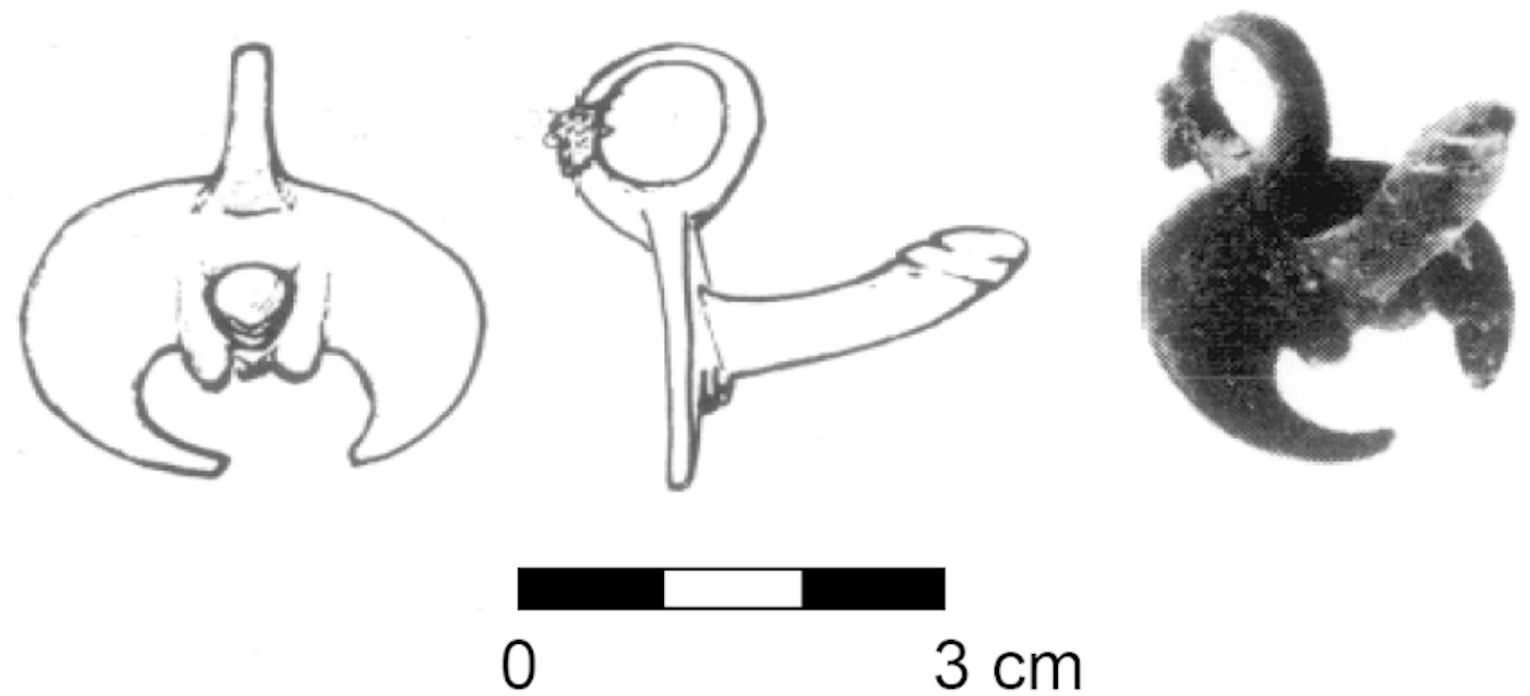

Figura 10. Amuleto fálico 'en pelta' de Arras (Paso de Calais, Francia). (Fuente: Jelski, 1984: 263, lám. 1, 7).

Realizar una semblanza historiográfica acerca de Baelo Claudia en unas pocas líneas implica por fuerza no poder ser exhaustivo en cuanto a la cantidad de trabajos que se han realizado en este enclave desde al menos el siglo XVIII. En este sentido, lo mejor es recomendar al lector publicaciones de síntesis, tanto arqueológica (Sillières, 1997) como bibliográfica (Rojas, 2009). La ciudad fue fundada en el siglo II a.C., probablemente como continuación de un antiguo poblado prerromano llamado Belo o Belón. Obtuvo el rango de municipio en el siglo I d.C. durante el mandato de Claudio, de ahí su epíteto. Por su ubicación costera y cercana al estrecho de Gibraltar, el asentamiento gaditano estuvo centrado económicamente en actividades pesqueras, salazoneras y comerciales con el norte de África. A partir del siglo II d.C., Baelo Claudia empezó a perder la importancia que tuvo hasta abandonarse en el siglo VII d.C.

En la actualidad se conocen varios espacios funerarios dentro del conjunto arqueológico, entre los que cabe destacar la llamada necrópolis occidental, ubicada junto a la puerta de Gades, el cementerio noreste de cronología tardoantigua y el camposanto oriental cercano a la puerta de Carteia (Prados y Jiménez, 2015). Precisamente, durante las excavaciones que se efectuaron en uno de sus cementerios entre 1917 y 1921 se localizaron amuletos similares. En algún caso estas piezas proceden de tumbas infantiles (Paris et al., 1926: 89). Se trata de una higa y dos amuletos fálicos realizados en pasta vítrea, un amuleto fálico facturado en nácar, cuatro amuletos con higa y falo en hueso de entre 4 y $2 \mathrm{~cm}$ de longitud de entre los cuales a uno le colgaba un hilo de bronce para suspenderlo, y órganos viriles en hueso sin número determinado (Paris et al., 1926: 89, 143-144, lám. XXII) (Figura 12).

\subsection{2. ¿Cerro de la Botinera? (Los Algodonales)}

Pieza 22. Amuleto fálico triple de bronce que preserva $5 \mathrm{~cm}$ de longitud. La pieza presenta argolla de suspensión en la zona superior central, conservando todavía la higa a la izquierda y el falo con sus testículos en la inferior, no así el presumible pene erecto que habría existido en la derecha (Figura 13). Se encuentra depositado actualmente en el Museo de Cádiz, sabiéndose únicamente que procede de Los Algodonales. №. inv. CE10779.

\section{El mal de ojo y los amuletos fálicos en época romana}

La información textual que ha llegado desde el mundo clásico hasta nuestros días sobre los amuletos fálicos es escasa en comparación a la existente sobre otros temas de índole religiosa. No obstante, los pocos testimonios literarios conocidos permiten proponer que los falos y las higas aquí presentados fueron utilizados como remedios y amuletos contra el mal de ojo. Con el ánimo de contextualizar su uso, en este último apartado se realiza una panorámica sobre el aojamiento en época romana tratando de dar respuesta a quiénes y cómo se creía que podían transmitirlo, de qué 

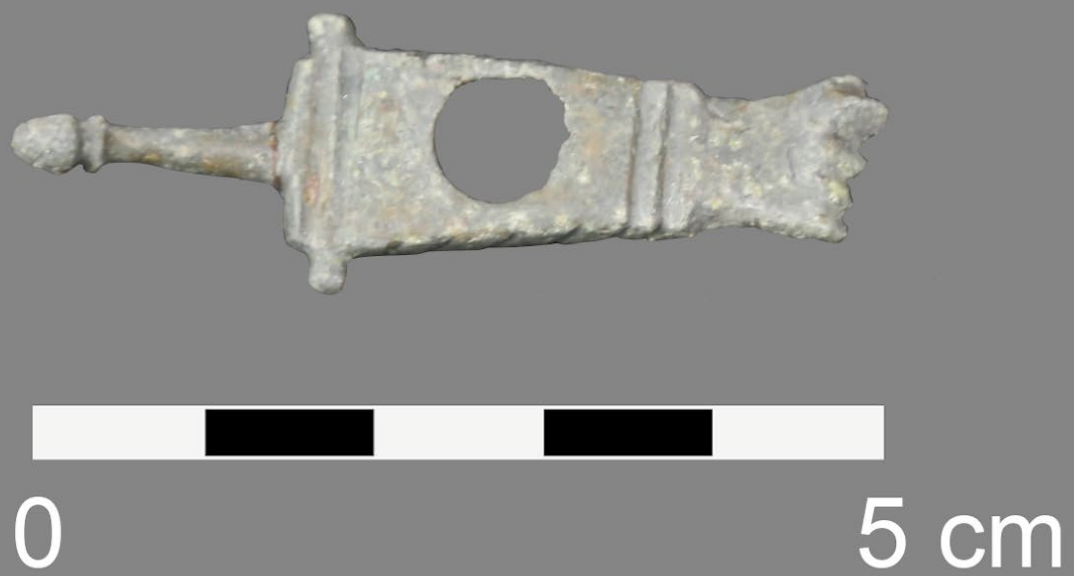

Figura 11. Amuleto fálico 'de ruleta' localizado en Baelo Claudia. (Fuente: a partir del Archivo Fotográfico del Conjunto Arqueológico de Baelo Claudia).

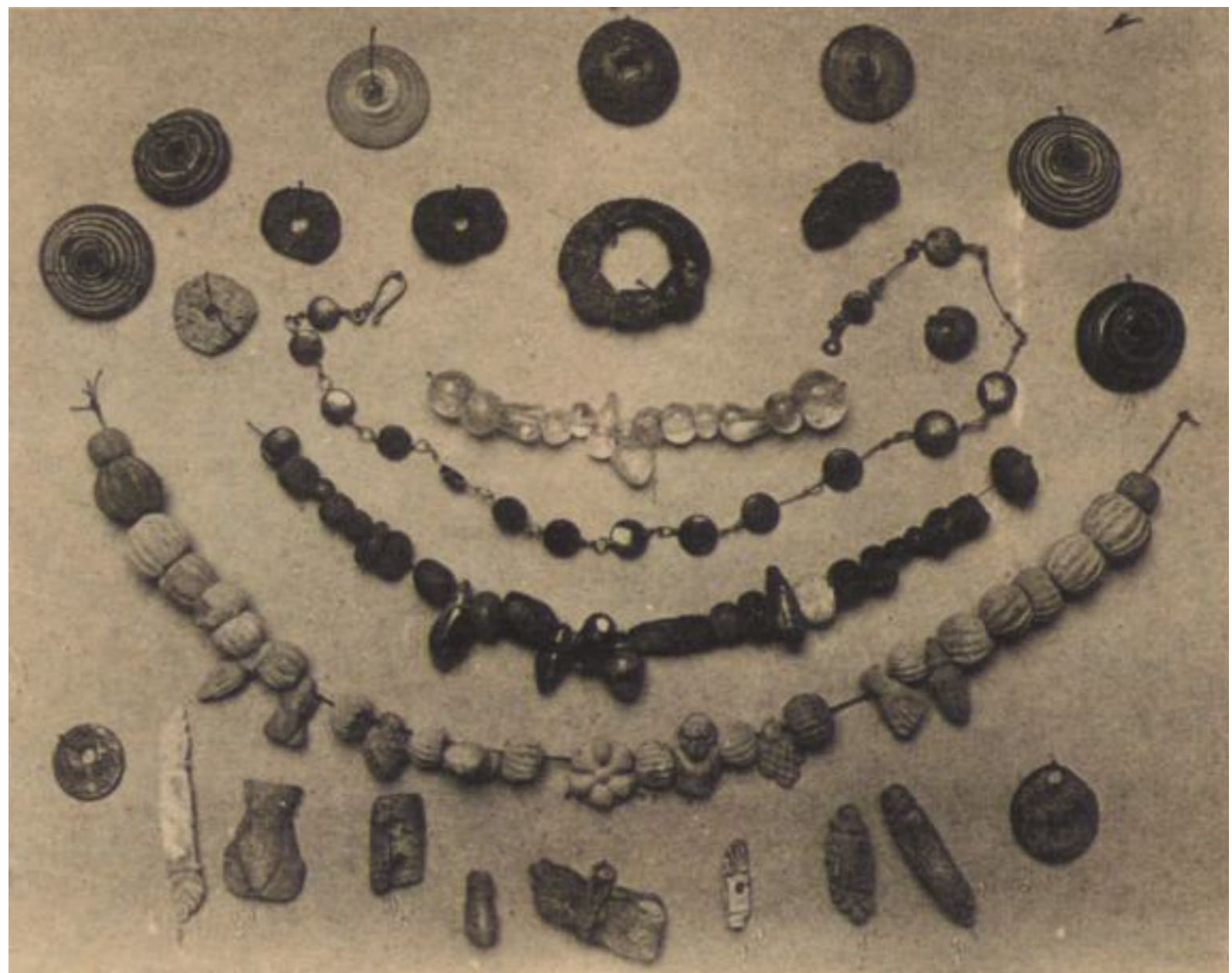

Figura 12. Varios amuletos fálicos e higas, alineados en la parte inferior de la imagen, procedentes de la necrópolis de Baelo Claudia. (Fuente: Paris et al., 1926: lám. XXII). 


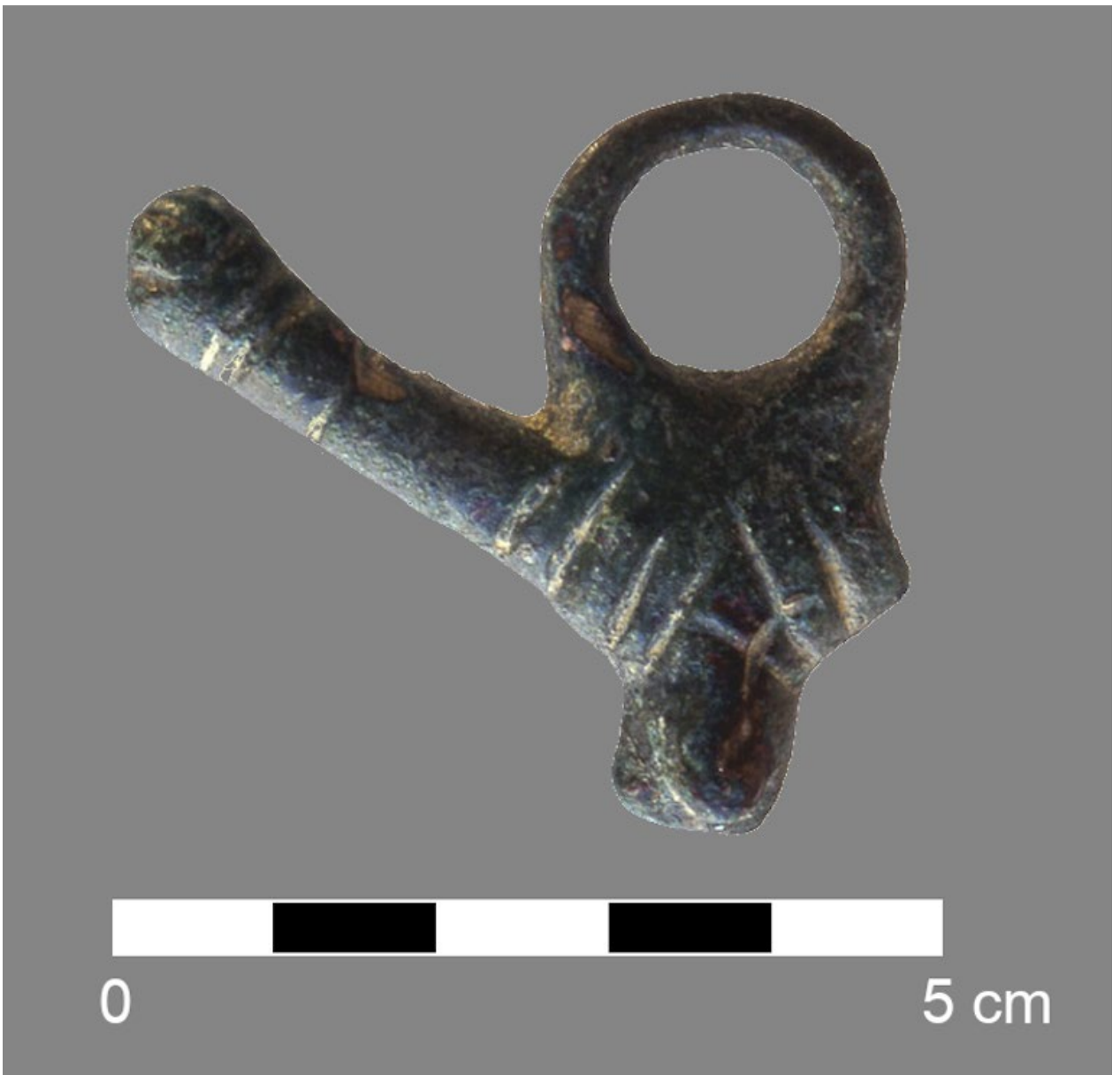

Figura 13. Amuleto fálico triple procedente de Los Algodonales. (Fuente: a partir de ceres.es).

manera era posible evitarlo, y porqué se utilizaron falos y símbolos fálicos para ello.

\section{1. ¿Quiénes podían transmitir el mal de ojo?}

De sobras es conocida la creencia en el mal de ojo en numerosas culturas tanto pasadas como actuales. Quienes aceptan su existencia admiten que algunas personas, de modo intencionado o no, pueden transmitirlo con su mirada sobre otros individuos y objetos, generando desgracias puntuales o haciendo que este problema les afecte durante períodos prolongados de tiempo. Esta condición necesaria, pero no suficiente, puede conllevar el empleo de amuletos para evitar tales infortunios (vid. Maloney, 1976).

Dentro del mundo antiguo, la creencia en propiedades inherentes en la mirada de determinadas personas era una práctica extendida. Así, la peculiar mirada es el denominador común del tuerto espartano Licurgo; de Oxilo, el guía de los Heráclidas al Peloponeso con uno o tres ojos según las tradiciones y de la Gorgona de mirada penetrante.
Precisamente, sobre esta mirada penetrante y el respeto que causaba hablaba Suetonio a propósito del emperador Augusto:

\begin{abstract}
"Sus ojos eran vivos y brillantes, y le gustaba incluso hacer creer que en ellos había una especie de fuerza divina, disfrutando si, al mirar a alguien fijamente, éste bajaba el rostro como ante el resplandor del sol." (Suetonio, Augusto, 79, 2; trad. Agudo, 1992: 264).
\end{abstract}

La monoftalmia, la trioftalmia o tener doble pupila entre otras particularidades ópticas también han sido características que han creado en el imaginario colectivo la concentración de una potencia en la mirada que puede permitir poderes sobrenaturales. Así se expresaba Plinio a propósito de las peculiares pupilas que tenían los individuos de algunas comunidades africanas:

"Asimismo en África, según Isígono y Ninfodoro, hay algunas familias de hechice- 
ros por cuyos elogios perece el ganado, se secan los árboles y mueren los niños. Añade Isígono que hay gente de la misma clase entre los tribalos y los ilirios, que hacen hechizos incluso con la mirada $y$ matan a aquellos a los que contemplan largo tiempo, especialmente con los ojos encolerizados; su maleficio se deja sentir con más facilidad en los adultos, y lo más notable es que tienen dos pupilas en cada ojo. Relata Apolónides que, en Escitia, también hay unas mujeres de esa clase, a las que llaman bicias. Filarco cuenta también que en el Ponto están los "tibios" $y$ otros muchos de las mismas características, cuyas marcas son que en un ojo tienen dos pupilas y en el otro la efigie de un caballo; [...]. Incluso entre nosotros, Cicerón afirma que, en cualquier parte, todas las mujeres que tienen dos pupilas hacen daño con la mirada. Hasta ese punto la naturaleza, habiendo puesto en el hombre la inclinación de las fieras de alimentarse con vísceras humanas, quiso poner también veneno en todo el cuerpo $e$, incluso, en los ojos de algunos, para que no existiera ninguna clase de mal que no estuviera en el hombre." (Plinio, Historia Natural, VII, 16-18; trad. Del Barrio et al., 2003: 14-15).

De la misma opinión era Ovidio sobre Dipsas:

"Hay una... (todo aquel que quiera conocer a una alcahueta, que preste oídos)... hay una vieja llamada Dipsas. De su modo de ser le viene el nombre. Ella nunca contempló, estando sobria, a la madre del negro Memnón sobre sus rosados caballos. Ella conoce las artes mágicas y los conjuros de Eea, y hace volver por medio de su arte las aguas corrientes a su manantial. Sabe bien cuál es la virtud de las hierbas, cuál la de las cintas movidas por la rueda sinuosa, cuál la del veneno de una yegua en celo. Con su sola voluntad, se aglomeran las nubes en toda la extensión del cielo; con su sola voluntad, brilla la luz en la límpida bóveda celeste. He visto, creedme, los astros centelleantes con el color de la sangre, y el rostro de la luna estaba purpúreo por la sangre. Tengo la sospecha de que, convertida en pájaro, revolotea a través de las sombras de la noche, y que su cuerpo de anciana se recubre de plumas. Tengo la sospecha y es lo que se dice. Además, la doble pupila de sus ojos despide rayos, y una luz centelleante surte de ambos globos oculares." (Ovidio, Amores, 1, 8, 1-16; trad. Cristóbal, 1989: 229).

\section{2. ¿Cómo se transmitía el mal de ojo?}

La creencia en el mal de ojo fue objeto de polémica en época romana entre quienes aceptaban y rechazaban su existencia. Entre los primeros, hubo autores que desde una corriente naturalista trataron de racionalizarlo apelando a unos efluvios que emanaban de la vista, tanto de humanos como de animales (Plinio, HN. VII, 80; XXIX, 66; XXIX, 90; Heliodoro, Etiópicas, III, 8, 2). A este respecto contamos con la información transmitida por Plutarco en su Moralia:

"Por cierto, dije yo, que, de algún modo, tú mis $\neg$ mo descubriste una huella y rastro de su causa [la del mal de ojo] al llegar a los efluvios de los cuerpos, pues el olor, la voz y la corriente de la respiración son ciertas emanaciones de los seres vivos y partículas que mueven los sentidos, cuan ᄀdo sufren su contacto. Y es mucho más natural que tales emanaciones partan de los seres vivos por su calor y movimiento, como si el hálito vital tuviera cierta palpitación y agitación por la cual, golpeado el cuerpo continuamente, despide ciertos efluvios, $y$ es natural que esto ocurra, sobre todo, a través de los ojos, pues la visión, al tener mucha movilidad, además de un hálito que emite brillo, esparce una admirable fuerza ardiente, de suerte que el hombre experimenta y hace muchas cosas mediante ella, pues atraí $\neg$ dos por los objetos visibles, está sujeto a los placeres y sinsabores correspondientes [...].

Pues bien, cuando, puesta en esta situación por la envidia, la gente clava sus miradas, como están enraiza $\neg$ das en lo profundo del alma, extrayendo su maldad de ella, caen como dardos envenenados, $y$ nada, pienso, ni absurdo ni increíble ocurre, si conmueven a quienes miran, pues también los mordiscos de los perros son 
más dañinos cuando muerden con rabia, y el esperma de los hombres prende más, cuando se unen enamorados, $y$, en general, los sentimientos del alma refuerzan y hacen más intensas las potencias del cuerpo. Por ello también creen que los llamados amuletos ayudan contra la envidia, ya que por su rareza es atraída la vista, de suerte que se clava menos en los que la sufren. Cuente para ti esto, Floro, como mi contribución al banquete." (Plutarco, Moralia, IV, Libro V, 7, 680-F-682a; trad. Martín García, 1987: 249-251).

\section{3. ¿Cómo se podía evitar el mal de ojo?}

Los creyentes en el mal de ojo entendían que el único remedio posible para evitarlo era apartar la mirada del aojador de las personas o de los objetos que se quisiera proteger. Para ello, en el mundo romano se recurrió a un conjunto heterogéneo de formas que fueron empleadas en muchas ocasiones como colgantes. Entre ellos se encuentran elementos y gestos sexuales como los que aquí nos ocupan. Junto a los amuletos con representaciones fálicas también se emplearon representaciones de genitales con similar carácter apotropaico decorando anillos, vasijas cerámicas, tintinabula, paredes e incluso murallas. El pequeño tamaño que presentaron en ocasiones los primeros casaría con los datos aportados por los autores clásicos a propósito de que tanto los anillos como los colgantes podrían haber sido utilizados principalmente por mujeres y niños. Un porqué para este hábito podría encontrarse en el alto porcentaje de mortalidad infantil y de parturientas en época romana (Alvar, 2010: 239; Scheidel, 2002: 21-23). También era común el uso de estos amuletos por parte de generales victoriosos, según narra Plinio (HN, XXVIII, 39). No obstante, como acertadamente comenta Alvar Nuño, se desconocen el sexo y la edad de muchos inhumados en cuyas tumbas se encuentran estas piezas como ajuar (Alvar, 2010: 239). En auxilio de esta idea se trae a colación un pasaje escrito por Varrón en el que indicaba la conveniencia de utilizar este tipo de objetos frente a los peligros del fascinum (mal de ojo):

"Por esto, lo feo tiene el nombre de obscaenum por el hecho de que, excepto en escena (scaena), no debe decirse públicamente. Puede deberse incluso al hecho de que a los niños se les cuelga en el cuello una cierta cosa algo fea, para que nada les dañe, denominada scaevola por razón de su buen augurio (scaeva)." (Varrón, De lengua latina, VII, 96-97; trad. Hernández Miguel, 1998: 67-68).

No es fácil saber si el término scaevola mencionado por Varrón en este pasaje hace alusión al tipo de amuletos que tratamos aquí (vid. Alvar, 2010: 166-167) o a las famosas bulas, pequeñas cápsulas que podían contener amuletos de carácter sexual o simples bolitas que sonaban contra las paredes del contenedor para atraer la mirada del fascinador. No obstante, no es descabellado plantear tal relación (Gómez, 2008: 332), pues hasta época contemporánea se han venido empleando este tipo de objetos para proteger a recién nacidos y niños de corta edad. Este es el caso de la higa, visible en el retrato de la infanta Ana María Mauricia, elaborado en 1602 por Juan Pantoja de la Cruz (Figura 14). Otra buena muestra de lo aquí expuesto son los amuletos con higa y representación de la virgen de la Cabeza de Andújar (Jaén) que suelen colgarse a día de hoy de las cunas de los bebés para protegerles (Figura 15).

La higa, realizada normalmente mediante la colocación del pulgar entre el índice y el corazón, se representó también con el puño cerrado y el dedo corazón extendido, gesto conocido con la expresión digitus impudicus. En ambos casos, el pulgar y el corazón habrían representado el pene introducido en la vulva. Según se desprende de los textos, este gesto parece que fue especialmente realizado por mujeres de avanzada edad:

"Mira, una abuela o tía materna temerosa
de los dioses ha sacado al niño de la cuna
y le hace conjuros primero en la frente y
en los labios húmedos con el dedo cora-
zón untado en salivas lustrales, experta
en rechazar los estragos del mal de ojo."
(Persio, Sátiras, 2, 30-34; trad. Cortés,
1988: 129).

"La vieja sacó de su seno una red tejida con hilos de varios colores y me la echó al cuello. Luego amasó con saliva un poco de polvo y, colocando la pasta en su dedo cordial, me marcó la frente a pesar de mi repugnancia... Concluido este encantamiento, me mandó escupir tres veces y 
echarme tres veces al bolsillo unas piedrecitas previamente encantadas por ella y envueltas en púrpura." (Petronio, Satiricón, 131, 4; trad. Rubio, 1978: 188-189).

El tercero, [se llama] impúdico, porque con frecuencia se expresa con él alguna burla infamante." (San Isidoro, Etimologías, XI, 71; trad. Oroz y Marcos, 1994: 25).

Similar papel cumplió en ocasiones la figura del dios Fascino, protector de los militares, según recogió Plinio:

“Debemos creer nosotros que es correcto que se haga a la llegada de un extraño o que, si mira a un bebé dormido, la nodriza escupa sobre él tres veces? Aunque a éstos los cuida Fascino, protector también de los generales, no sólo de los niños, divinidad cuyo culto entre los ritos religiosos romanos es atendido por las Vestales y que, médico del mal de ojo, ampara los ca- rros de los triunfadores colgado debajo de éstos y, como remedio similar a una voz, les ordena mirar atrás para conseguir a su espalda la benevolencia de la Fortuna, verdugo de la gloria." (Plinio, Historia Natural, XXVIII, 39; trad. Cantó et al., 2002: 474-475).

\section{4. ¿Por qué se usaban símbolos fálicos contra el mal de ojo?}

En muchos de los casos conocidos, con este tipo de objetos se pretendía hacer frente al aojamiento provocado de manera voluntaria o involuntaria por parte de quienes ponían su vista en una persona temerosa de ser 'fascinada'. El hecho de que el observado se sienta intimidado establece una relación desigual entre el 'aojador' y el 'aojado'. Esta relación desigual es perfectamente comparable a otro tipo de relaciones agresivas entre animales de una misma especie o de especies diferentes en las que la mirada juega un papel fundamental. De hecho, los seres humanos suelen evitar la mirada sostenida entre extraños $y$, por lo general, quien

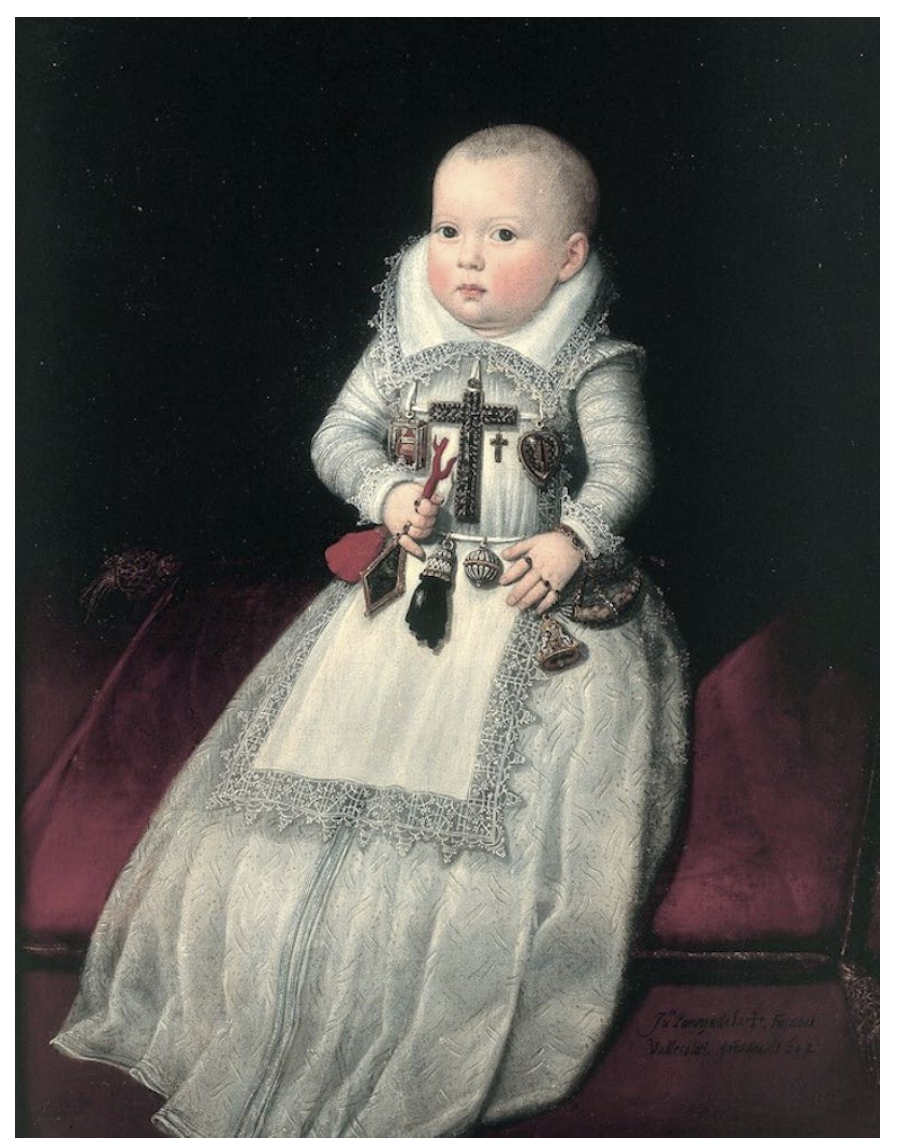

Figura 14. La infanta Ana María Mauricia (1602, Juan Pantoja de la Cruz). Óleo sobre lienzo. 85 x 75 cm. Madrid, Monasterio de las Descalzas Reales. (Fuente: Cobo, 2013: 26, fig. 5). 


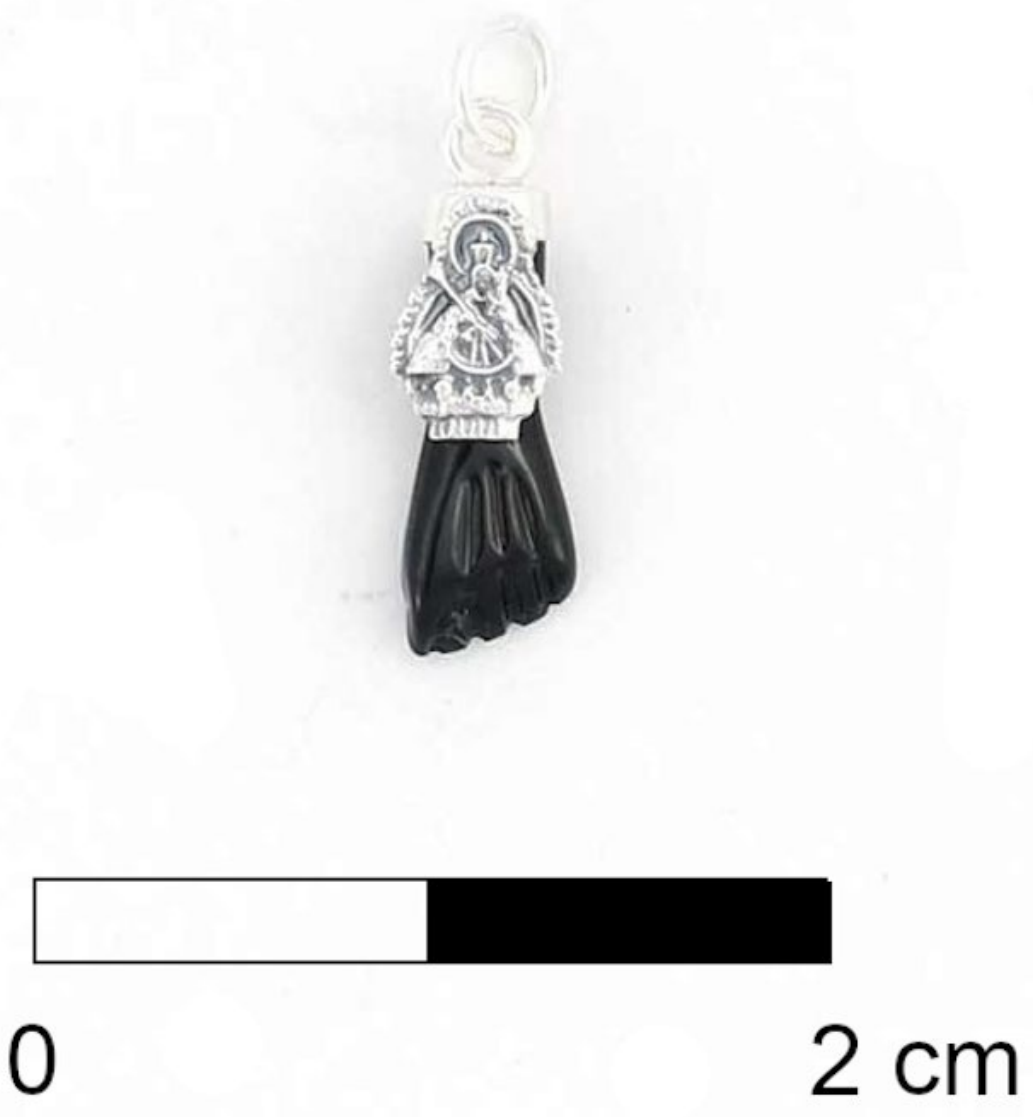

Figura 15. Amuleto con la representación de la virgen de la Cabeza de Andújar (Jaén) en su parte superior y la higa en la inferior. (Fuente: Elaboración propia).

la mantiene suele hacer prevalecer su autoridad. Cuestión similar ocurre entre otros primates, los cuales perciben del mismo modo esta sensación. Es la mirada intensa y prolongada, puesta demasiado tiempo sobre otro individuo, la que puede tener como consecuencia la muestra de agresividad por parte del que mira o del que es mirado. Ante esta sensación de temor, el falo pudo ser utilizado por diferentes motivos (vid. Rey, 1989: 233 y ss.; Alvar, 2010: 177 y ss.) que no tienen porqué ser contradictorios, sino complementarios.

La primera de las interpretaciones ha visto tanto a los penes como a las higas como símbolos impúdicos. Según esta hipótesis, el carácter malévolo de los aojadores encajaría con la ausencia de rectitud moral y la falta de recato propia de la mayoría de la población. Aceptando esta relación de conceptos, la falta de decoro personal daría rienda suelta a los instintos primarios del aojador, quien se entretendría mirando elementos de clara connotación sexual sin intención de apartar la mirada.
En apoyo de esta propuesta quizás pueda hacerse uso del pasaje de Varrón (Lin. Lat., VII, 96-97) anteriormente comentado en el cual se dice "que a los niños se les cuelga en el cuello una cierta cosa algo fea, para que nada les dañe".

Desde una segunda hipótesis se ha planteado que el falo, como símbolo de fecundidad, actuaría bajo la denominada 'magia antipática', contrarrestando la mirada del aojador en tanto que propiciatoria de la detención de la fertilidad y de la destrucción de lo vivo. El carácter vivificante otorgado al falo ha llegado hasta la actualidad en numerosas culturas. Cabe destacar aquí entre los muchos ejemplos históricos y actuales la ceremonia sintoísta del Kanamara Matsuri ('Festival del falo de metal'), en la cual se saca en procesión un pene para propiciar la fertilidad y la prosperidad de mujeres, cosechas y negocios, entre otros asuntos. En concordancia con esta idea, la función fertilizante del falo en los amuletos podría ponerse en conexión con la aparición de animales par- 
cialmente realizados en ocasiones en los mismos, caso del toro (Figura 16). De sobras es conocida a lo largo de la Historia la conexión de los bóvidos, especialmente toros y vacas, con la fertilidad de la naturaleza (vid. Delgado, 1996: 269-297).

Por último, una de las explicaciones dadas para el empleo de estos elementos se basa en el carácter amenazante del falo (Gómez, 2018). El uso del pene como arma intimidatoria es un recurso frecuente en otros primates como los cinocéfalos y los cercopitécidos. Éstos suelen exhibir sus genitales ante posibles amenazas externas para proteger al grupo mientras se alimenta con la guardia baja (Eibl-Eibesfeldt, 1977).

En consonancia con esta última hipótesis, el empleo del miembro viril como arma con la que atacar simbólicamente al enemigo cuenta con ejemplos tanto dentro del mundo apotropaico romano como en otros contextos mediterráneos. Dentro de la tradición latina se conocen varios mosaicos con representaciones de la lucha contra el mal de ojo en el que tanto los falos exentos, como saliendo de entre las piernas de personajes grotescos se diri- gen amenazantes hacia un ojo abierto junto a una serie de animales y objetos que igualmente lo atacan. Dentro de esta temática cabe resaltar aquí el famoso mosaico de la denominada 'casa del mal de ojo' de Antioquía (Turquía). En él, junto a la expresión KAICY ('lo mismo para ti') aparece representado un ojo abierto con un tridente y una espada clavados y sobre el que se abalanzan un escorpión, un cuervo, un perro, un felino, una serpiente y una lombriz. Junto a todos estos atacantes, un sileno de espaldas al ojo tiene figurado un pene de enormes proporciones que busca a éste (Figura 17).

Fuera del contexto romano, el empleo del pene como arma se encuentra por ejemplo en algunas representaciones del dios egipcio Bes. Esta deidad, famosa por su enanismo y su orondo perfil, fue por lo general para egipcios y fenicios una divinidad protectora de embarazadas, niños y difuntos. El carácter apotropaico de Bes se reflejó otorgándole a su imagen una mueca fiera, enseñando en ocasiones los dientes y la lengua, y haciéndole portador de espadas y serpientes en sus manos. Resulta sintomático para el caso que aquí nos ocupa que

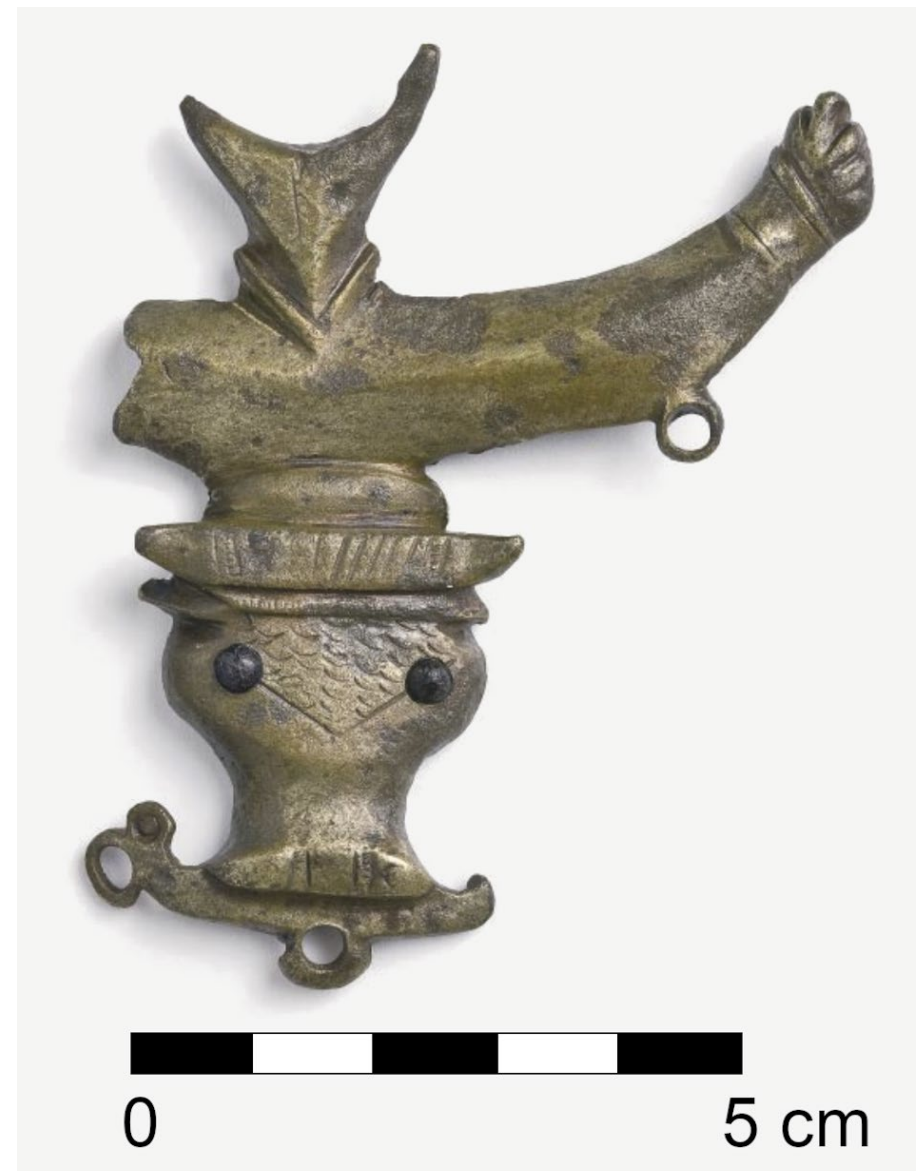

Figura 16. Amuleto con representación de higa en la parte superior derecha y cabeza de toro en su mitad inferior procedente de Colonia Celsa (Velilla de Ebro, Zaragoza). (Fuente: a partir de Paz y Ortiz, 2008: 25). 


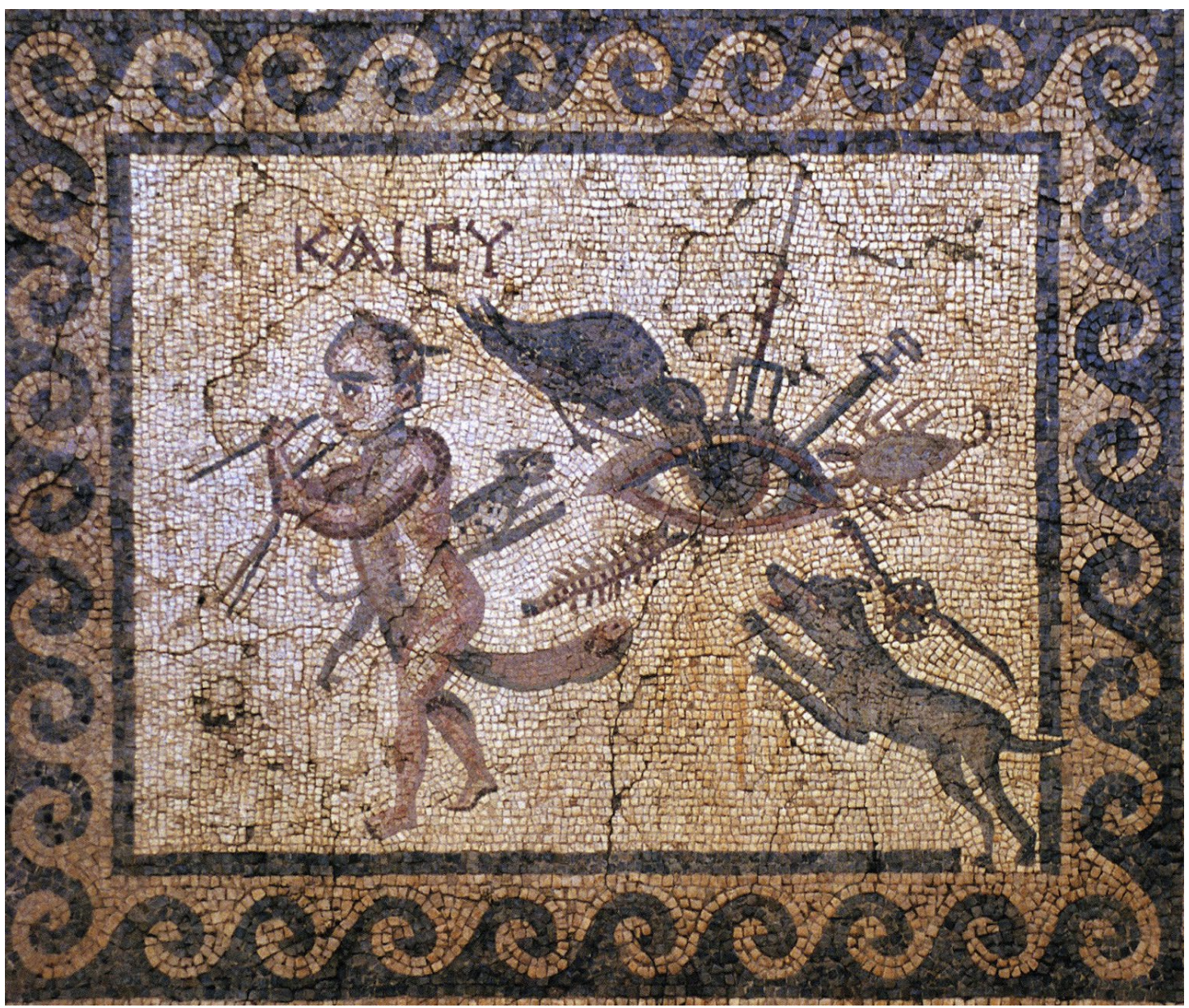

Figura 17. Mosaico contra el mal de ojo de la conocida como 'casa del mal de ojo' (Antioquía, Turquía). (Fuente: a partir de Alvar, 2010: 545).

en época grecorromana se representara a Bes, en ocasiones, itifálico y que sus espadas fueran sustituidas por falos (Figura 18).

\section{A modo de conclusión}

Con la publicación en estas páginas de veintidós nuevos ejemplares al corpus de amuletos fálicos de la provincia de Cádiz se ha cuadruplicado el número de objetos previamente conocidos con esta forma y función dentro del ámbito gaditano. Con la inclusión de ocho nuevos ejemplares procedentes de las inmediaciones de Medina Sidonia y Espera, planteamos que puede afirmarse el uso generalizado de estos objetos tanto en ámbitos netamente costeros como en zonas serranas. No obstante, los contextos precisos de estas piezas siguen resultando por lo general esquivos. Solamente podemos proponer con bastante probabilidad la procedencia funeraria de los amuletos localizados en Chipiona y en Espera, cuestión que sigue la pauta de piezas similares procedentes de Gades y Baelo Claudia.
Otra cuestión a destacar es la publicación de un ejemplar facturado en oro. Como se ha visto, la existencia de amuletos áureos es poco frecuente debido al valor de su materia prima, buscada por los ladrones de tumbas y fácilmente reciclable. En la revisión realizada para el presente estudio hemos documentado un total de siete piezas, a la que hay que añadir la procedente de Chipiona. A pesar de esto, las pocas piezas acreditadas guardan un patrón tipológico y de tamaño, sin que pueda por ello asegurarse la existencia de moldes para su realización. En relación con este asunto, tanto para el caso de los objetos de bronce como para los de oro, sigue siendo difícil plantear la localización de talleres en los que se pudieron haber elaborado. Quizás un análisis acerca de la procedencia del metal empleado podría arrojar algo de luz en este sentido, si bien somos conscientes de que el metal y el trabajo del mismo no tendrían por qué presentar una correlación geográfica estrecha.

Igualmente, hay que mencionar dos aspectos significativos en relación con la tipología de las pie- 


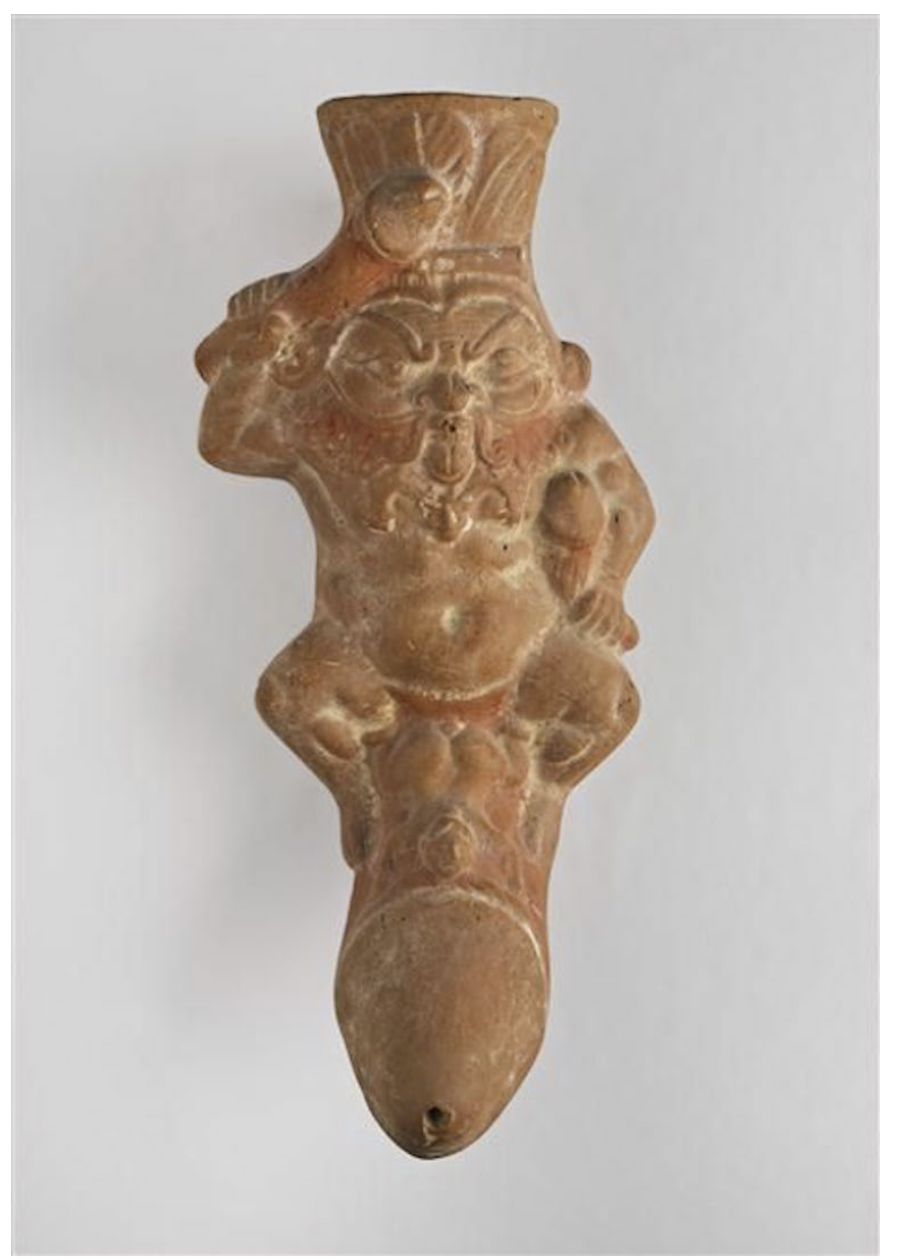

Figura 18. Terracota del dios egipcio Bes itifálico. (Fuente: a partir de Gómez y Rodríguez, 2013: 13).

zas aquí descritas. Por una parte, hay que destacar la existencia de amuletos fálicos simples sin argolla de suspensión ni testículos, probablemente difíciles de distinguir en algunas ocasiones de genuinos clavos de época romana. Por otro lado, se ha dado a conocer también en estas páginas un amuleto fálico en pelta, hasta donde hemos podido indagar desconocido en el sur de la península Ibérica y que tiene paralelos con ejemplares franceses procedentes de tumbas infantiles de época tardoantigua.

Por último, la falta de contexto y la imposibilidad de otorgar cronologías precisas a los amuletos fálicos a partir de su tipología y de sus detalles decorativos obliga a ser especialmente cautos con sus dataciones. Por lo general, estas piezas han venido siendo fechadas por los especialistas entre los siglos I a.C. y II d.C. No obstante, no hay que olvidar que ejemplares como el de Essex y el de Arras han sido fechados por sus excavadores en una cronología tan tardía como el siglo IV d.C., por lo que es probable que se haya venido utilizando un rango cronológico demasiado estrecho para los ejemplares hispanos.
Ante estos interrogantes e imprecisiones, sigue siendo necesario realizar un estudio pormenorizado de los amuletos fálicos romanos que se centre en resolver aspectos tipológicos, cronológicos y de dispersión geográfica desde los puntos de origen hasta los enclaves más tardíos.

\section{Agradecimientos}

Los autores del presente artículo quieren mostrar su agradecimiento a todas aquellas personas que han colaborado facilitando el acceso a las piezas aquí incluidas, así como información e imágenes de las mismas, de las cuales se tienen los permisos necesarios otorgados por sus correspondientes instituciones de origen. En especial queremos destacar a los miembros de la Asociación Cultural Caepionis de Chipiona; a Rosalía González Rodríguez y Francisco José Barrionuevo Contreras, antigua directora y técnico del Museo Arqueológico de Jerez de la Frontera; a Juan José López Amador, técnico del Museo Municipal de El 
Puerto de Santa María; a Pepa Lozano Ramírez, directora del Museo Arqueológico de Espera; a Salvador Montañés Caballero, director del Museo Arqueológico de Medina Sidonia; a Iván García Jiménez, responsable del Área de Investigación del Conjunto Arqueológico de Baelo Claudia; y a Juan Ignacio Vallejo y José María Jayme Castañeda, director y técnico del Museo de Cádiz. Cualquier error en estas páginas es responsabilidad única de los autores.

\section{Bibliografía}

AGUDO CUBAS, Rosa María (trad.). 1992: Suetonio. Vidas de los doce Césares I. Gredos. Madrid.

ALCÁZAR GODOY, José; SUÁREZ LÓPEZ, A.; ALARCÓN CASTELLANO, Francisco José. 1994: “Enterramientos infantiles en ánforas romanas". Revista de Arqueología, 164, pp. 36-47.

ALMAGRO-GORBEA, Martín; LORRIO ALVARADO, Alberto José. 1989: Segobriga III. La Muralla Norte y la Puerta Principal. Campañas 19861987. Diputación Provincial de Cuenca. Cuenca.

ALMAGRO-GORBEA, Martín; ABASCAL PALAZÓN, Juan Manuel. 1999: Segóbriga y su conjunto arqueológico. Real Academia de la Historia-Junta de Comunidades de Castilla-La Mancha. Madrid.

ALVARO NUÑO, Antón. 2010: El mal de ojo en el occidente romano: materiales de Italia, Norte de África, Península Ibérica y Galia. Tesis doctoral. Universidad Complutense de Madrid. Madrid.

ANDREU PINTADO, Javier; URRIZBURU JÁUREGUI, Ane. 2019: "Praefascinandae res: cuatro nuevos fascina fálicos procedentes del norte de la Tarraconense (Cinco Villas de Aragón, Zaragoza)". Anales de Arqueología Cordobesa, 30, pp. 319-332.

ANÓNIMO. 1867: "Artes y Arqueología”. Revista de Bellas Artes, 29, pp. 231-232.

ARACIL, Antonio; MARTÍNEZ, Roque. 1909: Reseña histórica-descriptiva del Santuario y Convento de Nuestra Señora de Regla (Chipiona, Cádiz). Tipográfica Católica. Barcelona.

BARREIRO ESPINAL, Fátima. 2004: Los amuletos romanos del Conventus Gaditanus. Memoria de Doctorado. Universidad de Cádiz.

BARREIRO ESPINAL, Fátima. 2009: Memoria final de la excavación extensiva en el solar $n^{\circ} 86$ de la Avenida de Sevilla, Chipiona, Cádiz. № Exp. 496/08. Delegación Provincial de Cultura de la Junta de Andalucía. Cádiz. Inédito.
BARREIRO ESPINAL, Fátima. 2011: "Los amuletos romanos de Cádiz y su carácter mágico". En J.J. DÍAZ; A.M. SÁEZ; E. VIJANDE y J. LAGÓSTENA (eds.): Estudios recientes de Arqueología Gaditana. Actas de las Jornadas de Jóvenes Investigadores en Prehistoria \& Arqueología (Cádiz, abril 2008), pp. 259-267. Archaeopress. Oxford.

BELTRÁN FORTES, José; LOZA AZUAGA, María Luisa; MONTAÑÉS CABALLERO, Salvador. 2018: Esculturas romanas de Asido (Medina Sidonia, Cádiz). Universidad de Sevilla. Sevilla.

CANTÓ, Josefa; GÓMEZ SANTAMARÍA, Isabel; GONZÁLEZ MARÍN, Susana; TARRIÑO, Eusebia (trads.) .2002: Plinio. Historia Natural. Gredos. Madrid.

CARMONA, Diego. 1635-1639: Historia sacra del insigne origen y raro aparecimiento de la antiquísima imagen de Nuestra Señora de Regla y sus admirables y maravillosas obras. BNE. Sede de Recoletos. MSS/1177. Inédito.

CHIC GARCÍA, Genaro. 1979-1980: "Lacca”. Habis, 10-11, pp. 255-278.

COBO DELGADO, Gemma. 2013: "Retratos infantiles en el reinado de Felipe III y Margarita de Austria: entre el afecto y la política". Anuario del Departamento de Historia y Teoría del Arte, 25, pp. 23-42.

CORTÉS TOVAR, Rosario (trad.). 1988: Persio. Sátiras. Gredos. Madrid.

CRISTÓBAL LÓPEZ, Vicente (trad.). 1989: P. Ovidio Nasón. Amores. Arte de Amar. Sobre la cosmética del rostro. Gredos. Madrid.

DARDAINE, Sylvie; Didierjean, François; LUNAIS, Sophie; PAULIAN, Agnès. 1979: "La treizième campagne de fouilles de la Casa de Velazquez à Belo (Bolonia-Cadix) en 1978". Mélanges de la Casa de Velázquez, XV, pp. 515-557.

DASEN, Véronique. 2003: "Les amulettes d'enfants dans le monde gréco-romain". Latomus, 62 (2), pp. 275-289.

DE LA BARRERA ANTÓN, José Luis; VELÁZQUEZ JIMÉNEZ, Agustín. 1988: "Amuletos romanos de Mérida". En Homenaje a Samuel de los Santos, pp. 211-214. Instituto de Estudios Albacetenses “Don Juan Manuel”. Albacete.

DEL BARRIO SANZ, Encarnación; GARCÍA ARRIBAS, Ignacio; MOURE CASAS, Ana María; HERNÁNDEZ MIGUEL, Luis Alfonso; ARRIBAS HEMÁEZ, María Luisa (trads.). 2003: Plinio el Viejo. Historia Natural. Libros VII-XI. Gredos. Madrid. 
DEL HOYO CALLEJA, Javier; VÁZQUEZ HOYS, Ana María. 1994: "Ensayo de sistematización de los amuletos fálicos en Hispania". Sexo, muerte y religión en el mundo clásico, pp. 235-259. Ediciones Clásicas. Madrid.

DEL HOYO CALLEJA, Javier; VÁZQUEZ HOYS, Ana María. 1996: "Clasificación funcional y formal de amuletos fálicos en Hispania". Espacio, Tiempo y Forma, Serie II, Historia Antigua, 9, pp. 441-466.

DELGADO LINACERO, Cristina. 1996: El toro en el Mediterráneo. Análisis de su presencia y significado en las grandes culturas del mundo antiguo. Universidad Autónoma de Madrid. Madrid.

EIBL-EIBESFELDT, Irenaus. 1977: El hombre preprogramado. Alianza. Madrid.

ENGEL, Arthur. 1900: "Nouvelles". Revue des Études Anciennes, 2 (1), pp. 70.

ESTEVE GUERRERO, Manuel. 1945: Excavaciones de Asta Regia (Mesas de Asta, Jerez). Campaña de 1942-43. Ministerio de Educación Nacional. Madrid.

ESTEVE GUERRERO, Manuel. 1950: Excavaciones de Asta Regia (Mesas de Asta, Jerez). Campaña de 1945-46. Ministerio de Educación Nacional. Madrid.

ESTEVE GUERRERO, Manuel. 1962: Excavaciones de Asta Regia (Mesas de Asta, Jerez). Campañas de 1949-50 y de 1955-56. Centro de Estudios Históricos Jerezanos. Jerez de la Frontera.

ESTEVE GUERRERO, Manuel. 1969: "Asta Regia: Una ciudad tartésica". Tartessos y sus problemas. V Symposium internacional de Prehistoria Peninsular, pp. 111-118. Universidad de Barcelona. Barcelona.

FERNÁNDEZ-CHICARRO Y DE DIOS, Concepción. 1962: "Informe arqueológico de los hallazgos más sobresalientes habidos en Andalucía durante el bienio 1959-1961". Actas del VII Congreso Arqueológico Nacional, pp. 65-75. Universidad de Zaragoza. Zaragoza.

FILLOY, Idoia. 1997: "Testimonio en torno al mundo de las creencias en época romana en el Territorio alavés". Isturitz, 9, pp. 765-795.

GALVE IZQUIERDO, María Pilar. 1983: "El amuleto fálico con cabeza de toro de Varea (Rioja)". Caesaraugusta, 57-58, pp. 111-133.

GARCÍA JIMÉNEZ, Iván; ZULETA ALEJANDRO, Francisco; PRIETO REINA, Óscar. 2004: “El yacimiento romano de El Torno-Cementerio de San Isidro del Guadalete". En D. BERNAL y L.
LAGOSTENA (eds.): Figlinae Baeticae. Talleres alfarerosy producciones cerámicas en la Bética romana (ss. II a.C.- VII d.C.). Actas del Congreso Internacional (Cádiz, 12-14 de noviembre de 2003), vol, 2, pp. 663-666. Archaeopress. Oxford.

GARCÍA VARGAS, Enrique. 2000: "Seiscientos años de ánforas gaditanas: 200 a.C.-400 d.C." En Actas de las VII Jornadas de Historia de Puerto Real, pp. 171-188. Ayuntamiento de Puerto Real. Puerto Real.

GIL ZUBILLAGA, Eliseo. 1994: "Presentación de la 1a Campaña de excavaciones en Iruña/Veleia". Revista de Arqueología, 160, pp. 58.

GÓMEZ PEÑA, Álvaro. 2008: "Amuleto fálico romano hallado en La Puebla del Río (Sevilla)". Spal, 17, pp. 329-334.

GÓMEZ PEÑA, Álvaro. 2018: "Tras las huellas de lo divino: darwinismo, religión y arqueología". En J.L. ESCACENA y L.-G. PÉREZ-AGUILAR (coords.): Todos en el Beagle. Darwinismo y Ciencias Históricas, pp. 51-79. Universidad de Sevilla. Sevilla.

GÓMEZ PEÑA, Álvaro; RODRÍGUEZ MELLADO, Jesús. 2013: "Amuleto fálico con higa procedente de Chipiona (Cádiz)". Ligustinus, 2, pp. 9-14. GONZÁLEZ FERNÁNDEZ, Julián. 1982: Inscripciones romanas de la provincia de Cádiz. Diputación Provincial de Cádiz. Cádiz.

GONZÁLEZ FERNÁNDEZ, Julián. 2011a: “Colonia Hasta quae Regia dicitur". En J. GONZÁLEZ y J.C. SAQUETE (eds.): Colonias de César y $\mathrm{Au}$ gusto en la Andalucía romana, pp. 223-247. "L'Erma" di Bretschneider. Roma.

GONZÁLEZ FERNÁNDEZ, Julián. 2011b: "Asido quae Caesarina". En J. GONZÁLEZ y J.C. SAQUETE (eds.): Colonias de César y Augusto en la Andalucía romana, pp. 273-298. "L’Erma" di Bretschneider. Roma.

GONZÁLEZ FERNÁNDEZ, Julián. 2014: "Inscripción romana del yacimiento de Gibalbín (Cádiz) con indicación de su condición de municipio". Spal, 23, pp. 191-196.

GONZÁLEZ RODRÍGUEZ, Rosalía; RUIZ MATA, Diego. 1999: "Prehistoria e Historia Antigua de Jerez". En D. CARO (coord.): Historia de Jerez de la Frontera. Tomo I. De los orígenes a la Época Medieval, pp. 19-188. Diputación de Cádiz. Cádiz.

GONZÁLEZ RODRÍGUEZ, Rosalía; BARRIONUEVO CONTRERAS, Francisco José. 2020: Guía-catálogo del Museo Arqueológico Municipal de 
Jerez de la Frontera. La historia de Jerez en sus colecciones. Presea. Jerez de la Frontera.

GUTIÉRREZ LÓPEZ, José María; PRIETO CORIA, María Concepción; RUIZ GIL, José Antonio. 1995: "Yacimientos neolíticos al aire libre con cardiales: el asentamiento de Esperilla (Espera, Cádiz). Propuesta de otro modelo de neolitización para Andalucía occidental”. Rubricatum, 1, pp. 627-638.

HENING, Martin.; McGREGOR, Arthur. 2004: Catalogue of the Engraved Gems and Finger-Rings in the Ashmolean Museum II. Roman. Archaeopress. Oxford.

HERNÁNDEZ MIGUEL, Luis Alfonso. (trad.) 1998: Varrón. La lengua latina. Libros VII-X y fragmentos. Gredos. Madrid.

HERRERA JIMÉNEZ, Mercedes; RODRÍGUEZ MELLADO, Jesús. 2014: Memoria Preliminar-Final Estudio de materiales arqueológicos depositados en el Museo Provincial de Cádiz pertenecientes a la intervención "Excavación Extensiva en el solar número 86 de la Avenida de Sevilla (Cádiz)". Ref.: DPPH-A-190/14 (1030). Delegación Provincial de Cultura de la Junta de Andalucía. Cádiz. Inédito.

HURTADO PÉREZ, Víctor; PERDIGONES MORENO, Lorenzo. 1983: "Ídolos inéditos del calcolítico en el sudoeste hispano". Madrider Mitteilungen, 24, pp. 46-58.

JELSKI, Georges. 1984: "Pendentifs phalliques, clochettes et peltae dans les tombes d'enfants". Revue du Nord, 66 (260), pp. 261-280.

JOHNS, Catherine; WISE, Philip J. 2003: "A Roman Gold Phallic Pendant from Braintree, Essex". Britannia, 34, pp. 274-276.

LAGÓSTENA BARRIOS, Lázaro Gabriel. 2011: "Asido Caesarina: la antigüedad romana de Medina Sidonia". En D. CARO (coord.): Historia de Medina Sidonia. Tomo 1. De los orígenes a la época medieval, pp. 115-191. Diputación de Cádiz. Cádiz.

LÓPEZ AMADOR, Juan José; PÉREZ FERNÁNDEZ, Enrique. 2013: El puerto gaditano de Balbo. El Puerto de Santa María. Cádiz. El Boletín. El Puerto de Santa María.

LUZÓN NOGUÉ, José María; LEÓN CASTRO, María Pilar. 1971: "Esculturas romanas de Andalucía". Habis, 2, pp. 233-250.

MADRAZO, Pedro. 1884: España, sus monumentos y artes. Su naturaleza e historia: Sevilla y Cádiz. Editorial de Daniel Cortezo y Cia. Barcelona. MALONEY, Clarence (ed.). 1976: The Evil Eye. Nue- va York

MARTÍN-ARROYO, Daniel Jesús. 2018: Colonización romana y territorio en Hispania. El caso de Hasta Regia. Universidad de Barcelona. Barcelona.

MARTÍN GARCÍA, Francisco (trad.). 1987: Plutarco. Obras morales y de costumbre (Moralia) IV. Charlas de sorbremesa. Gredos. Madrid.

MARTÍNEZ MUNILLA, Carolina. 1949: "Vaso de terra sigillata hallado en las inmediaciones del Santuario de Nuestra Señora de Regla (Chipiona)". Archivo Español de Arqueología, 22 (76), pp. 237-240.

MAS GARCÍA, Julio. 1985: “El polígono submarino de Cabo de Palos. Sus aportaciones al estudio del tráfico marítimo antiguo". En VI Congreso Internacional de Arqueología Submarina: Cartagena 1982, pp. 153-171. Ministerio de Educación Cultura y Deporte. Madrid.

MIÑANO DOMÍNGUEZ, Ana Isabel. 2006: "Los fondos museográficos del Museo Nacional de Arqueología Marítima. Las Amoladeras". Cuadernos de Arqueología Marítima, 7, pp. 8-15.

MONTAÑÉS CABALLERO, Salvador. 1993: "Ingeniería hidráulica romana en Medina Sidonia (Cádiz)". Revista de Arqueología, 146, pp. 3239.

MONTAÑÉS CABALLERO, Salvador. 1995: "Intervención arqueológica en las conducciones subterráneas de agua romanas de Medina Sidonia, Cádiz". Anuario Arqueológico de Andalucía/1991. Tomo III, pp. 65-74. Junta de Andalucía. Sevilla.

MONTAÑÉS CABALLERO, Salvador. 1998: “Excavaciones arqueológicas y actuaciones de rehabilitación y protección en estructuras romanas". Anuario Arqueológico de Andalucía/1994. Tomo III, pp. 21-31. Junta de Andalucía. Sevilla.

MONTAÑÉS CABALLERO, Salvador; AGUILERA RODRÍGUEZ, Luis. 2002a: "Actuación arqueológica de urgencia en solar de la C/ Álamo № 7-9 de Medina Sidonia (Cádiz)". Anuario Arqueológico de Andalucía/1998. Tomo III.1, pp. 118-123. Junta de Andalucía. Sevilla.

MONTAÑÉS CABALLERO, Salvador; AGUILERA RODRÍGUEZ, Luis. 2002b: "Actuación arqueológica de urgencia en el solar de la C/ San Francisco no 19 y C/ Guzmán № 1 de Medina Sidonia (Cádiz)". Anuario Arqueológico de Andalucía/1998. Tomo III.1, pp. 124-127. Junta de Andalucía. Sevilla. 
MONTAÑÉS CABALLERO, Salvador; MONTAÑÉS CABALLERO, Manuel. 2006: "El Cardo Maximus de Asido Caesarina. Excavación arqueológica y puesta en valor de un tramo de calle romana en Medina Sidonia (Cádiz)". Anuario Arqueológico de Andalucía/2002. Tomo III.1, pp. 176-182. Junta de Andalucía. Sevilla.

MONTAÑÉS CABALLERO, Salvador; MONTAÑÉS CABALLERO, Manuel. 2009a: "Actuación arqueológica preventiva: finca de la c/ Ganado no 1 Medina Sidonia (Cádiz)". Anuario Arqueológico de Andalucía/2004. Tomo I, pp. 382397. Junta de Andalucía. Sevilla.

MONTAÑÉS CABALLERO, Salvador; MONTAÑÉS CABALLERO, Manuel. 2009b: "Actuaciones arqueológicas preventivas: Huerto Moreno, parcelas números 6 y 7. Medina Sidonia (Cádiz)”. Anuario Arqueológico de Andalucía/2004. Tomo I, pp. 133-135. Junta de Andalucía. Sevilla.

MONTERO VÍTORES, Jesús. 2000: "Hacia una interpretación del problema de Ceret". Revista de Historia de Jerez, 6, pp. 61-83.

MONTERO VÍTORES, Jesús. 2019: “Asta, Gibalbín y Ugia. Nuevas propuestas de investigación desde el paralelo 37을 de Ptolomeo". Revista de Historia de Jerez, 22, pp. 61-77.

MORENA LÓPEZ, José Antonio; ROMERO CONDE, José Santiago. 2015: "La colección de amuletos fálicos romanos del Museo Histórico Municipal de Baena (Córdoba)". Antiquitas, 27, pp. 95-110.

OROZ RETA, José; MARCOS CASQUERO, Manuel Antonio (trads.). 1994: San Isidoro de Sevilla. Etimologías II. Madrid.

PARIS, Pierre; BONSOR, George; LAUMONIER, Alfred; RICARD, Robert; DE MERGELINA, Cayetano. 1926: Fouilles de Belo (Bolonia, province de Cadix, 1917-1921). Férét \& Fils. Paris-Bordeaux.

PARKER, Anthony John. 1992: Ancient Shipwrecks of the Mediterranean and the Roman Provinces. Archaeopress. Oxford.

PAZ PERALTA, Juan Ángel; ORTIZ PALOMAR, Esperanza. 2008: "La magia del toro en la cultura mediterránea y en el Aragón antiguo. El toro y su polisemia cultural: recurso, divinidad, zodiaco, ofrenda, linaje, signum, emblema, juegos circenses, amuleto". En R. CENTELLAS y J. COLAS (coords.): Toros y toreros en Aragón, pp. 13-47. Museo de Zaragoza. Zaragoza.

PERDIGONES MORENO, Lorenzo. 1987: Carta Ar- queológica de Arcos de la Frontera, Cádiz. Memoria de Licenciatura. Universidad de Sevilla. Sevilla.

PERDIGONES MORENO, Lorenzo; JIMÉNEZ PÉREZ, Concepción; AGUILERA RODRÍGUEZ, Luis. 1991: "Excavación arqueológica de urgencia en el Cerro de Esperilla. Espera, Cádiz". Anuario Arqueológico de Andalucía 1989. Tomo III, pp. 71-77. Junta de Andalucía. Sevilla.

PÉREZ LÓPEZ, Inmaculada. 1999: Leones romanos en Hispania. Fundación de Estudios Romanos. Madrid-Sevilla.

POVEDA, Ana María. 2009: "Pendiente amuleto/ talismán fálico". Sexo y erotismo: Roma en Hispania, p. 170. Museo Arqueológico de Murcia. Murcia.

POZO RODRÍGUEZ, Salvador F. 2002: "Varia arqueológica de la provincia Baetica. Bronces romanos inéditos. Grandes bronces. Estatuillas. Mobiliario doméstico. Amuletos fálicos. Espejos. Balanzas. Contrapesos. Asas y apliques de sítulas. Atalaje de caballerías". Antiquitas, 14, pp. 69-121.

PRADOS MARTÍNEZ, Fernando; JIMÉNEZ VIALÁS, Helena (eds.) 2015: La muerte en Baelo Claudia. Necrópolis y ritual en el confín del Imperio romano. Universidad de Cádiz y Universidad de Alicante. Cádiz y Alicante.

RAMOS MUÑOZ, José; VALVERDE LASANTA, María, M.; ROMERO SÁNCHEZ, José Luis; ALMAGRO BLÁZQUEZ, Agustín. 1991a: "La tecnología lítica de la transición del Neolítico a la Edad del Cobre en la zona centro-occidental de Cádiz". Zephyrus, 44, pp. 207-221.

RAMOS MUÑOZ, José; SANTIAGO PÉREZ, Antonio; MATA ALMONTE, Esperanza; GILES PACHECO, Francisco; MOLINA CARRIÓN, María Isabel; GUTIÉRREZ LÓPEZ, José María. 1991b: “Fuensanta. Un gran taller del Calcolítico y Bronce en la presierra del NE de Cádiz". Butlletí de l'Associació Arqueológica de Castelló «Llansol de Romaní», 9-11, pp. 68-84.

RAMOS MUÑOZ, José; GILES PACHECO, Francisco; SANTIAGO PÉREZ, Antonio; GUTIÉRREZ LÓPEZ, José María; VALVERDE LASANTA, María; MATA ALMONTE, Esperanza. 1992: "Explotación de los recursos líticos en la Prehistoria Reciente de Cádiz". Revista de Arqueología, 136, pp. 6-17.

REY SEARA, Eusebio. 1989: "Notas sobre la fascinación en la antigüedad". Gallaecia, 11, pp. 229-238. 
RODRÍGUEZ MELLADO, Jesús. 2017: La implantación territorial romana en la Costa Noroeste de Cádiz: el lacus Ligustinus como eje vertebrador del Poblamiento. Tesis doctoral. Universidad de Sevilla. Sevilla.

RODRÍGUEZ MELLADO, Jesús; GARRIDO GONZÁLEZ, Pablo; VÁZQUEZ PAZ, Jacobo. 2018: "La excavación arqueológica: resultados". En J. RODRÍGUEZ; P. GARRIDO y J. VÁZQUEZ (eds. cients.): La necrópolis tardoantigua de la Plaza del Humilladero de Ntra. Sra. de Regla (Chipiona, Cádiz): primera campaña de excavaciones arqueológicas (2015), pp. 35-48. Asociación Cultural Caepionis. Madrid.

ROJAS PICHARDO, Francisco Javier. 2009: “Bibliografía para el conocimiento de la ciudad hispanorromana de Baelo Claudia". Aljaranda, 72, pp. 37-51.

ROLLAND, Henri. 1965: Bronzes antiques de haute provence (Basses-Alpes, Vaucluse). CNRS. Paris.

ROMERO DE TORRES, Enrique. 1934: Catálogo Monumental de España. Provincia de Cádiz (1908-1909). Ministerio de Instrucción Pública y Bellas Artes. Madrid.

RUIZ CASTELLANOS, Antonio; VEGA, Eugenio J.; GARCÍA, Francisco A. 2016: Inscripciones latinas de Jerez de la Frontera. Epigrafía y contexto. Universidad de Cádiz. Cádiz.

SÁENZ PRECIADO, J. Carlos; LASUÉN ALEGRE, María Dolores. 2004: "El amuleto fálico de oro de Bilbilis (Calatayud-Zaragoza)". Saldvie. Estudios de Prehistoria y Arqueología, 4, pp. 221227.

SÁEZ BOLAÑO, José Antonio; BLANCO VILLERO, José María. 1996: Las monedas de la Bética Romana. Vol. I. Conventus Gaditanus. Numismática Ávila. San Fernando.
SCHEIDEL, Walter. 2002: "Progress and Problems in Roman Demography". En W. SCHEIDEL (ed.): Debating Roman Demography, pp. 1-81. Brill. Leiden.

SILLIÈRES, Pierre. 1977: "Prospections le long de la Via Augusta". Habis, 8 pp. 331-343.

SILLIÈRES, Pierre. 1997: Baelo Claudia: una ciudad romana de la Bética. Casa de Velázquez. Madrid.

TEJERA GASPAR, Antonio. 1979: Las tumbas fenicias y púnicas del Mediterráneo Occidental (estudio tipológico). Universidad de Sevilla. Sevilla.

TOVAR, Antonio. 1974: Iberische Landeskunde. Zweiter Teil: Die Völkerund die Städte des antiken Hispanien, I: Baetica. Baden-Baden.

VÁZQUEZ HOYS, Ana María. 2009: "Los amuletos o talismanes fálicos de Hispania". Sexo y erotismo: Roma en Hispania, pp. 42-67. Museo Arqueológico de Murcia. Murcia.

VIVES, José. 1942: Inscripciones cristianas de la España romana y visigoda. Barcelona.

VV.AA. 2010: Plan General de Ordenación Urbanística de Arcos de la Frontera. Vol. III (2). Ayuntamiento de Arcos de la Frontera. Arcos de la Frontera.

ZARZALEJOS, María del Mar; AURRECOECHEA, Joaquín; FERNÁNDEZ, Carmen. 1988: “Amuletos fálicos romanos inéditos de las provincias de Madrid y Toledo". Cuadernos de Prehistoria y Arqueología de la Universidad Autónoma de Madrid, 15, pp. 301-316. 